\title{
An Institutional Approach to Gender Diversity and Firm Performance
}

\author{
Forthcoming in Organization Science \\ Letian Zhang \\ Harvard Business School
}

This study examines data from 35 countries and 24 industries to understand the relationship between gender diversity and firm performance. Previous studies report conflicting evidence: some find that gender-diverse firms experience more positive performance and others find the opposite. However, most research to date has focused on a single country or industry and has not accounted for possible variation across social contexts. This paper advances an institutional framework and predicts that gender diversity's relationship with performance depends on both its normative and regulatory acceptance in the broader institutional environment. Using a unique longitudinal sample of 1,069 leading public firms around the world, I find that the relationship between gender diversity and firm performance varies significantly across countries and industries due to differences in institutional context. The more gender diversity has been normatively accepted in a country or industry, the more gender-diverse firms experience positive market valuation and increased revenue. These findings underscore the importance of the broader social context when considering the relationship between gender diversity and firm performance.

Keywords: diversity, gender, performance, institutional theory, cross-national, global.

\section{Acknowledgements}

I gratefully acknowledge the comments from Bart Bonikowski, Jason Beckfield, Nancy DiTomaso, Frank Dobbin, Robin Ely, Simo Goshev, Alexandra Killewald, Tim Liao, Elena Obukhova, Corinne Post, Orlando Richard, Ned Smith, and two anonymous OS reviewers. 


\section{INTRODUCTION}

The women's rights movement has increased the number of women in workforces around the world (Ali, Kulik, and Metz, 2011), which has in turn raised the question of how the gender diversity within a given organization affects its outcomes. Recent work has generally taken one of two broad approaches. One suggests that gender diversity may serve as a signal to investors and other external stakeholders and influence their perceptions of a firm's value (Dobbin and Jung 2011; Lee and James 2007; Smith and Gaughan 2016; Wright et al. 1995). A second line of work focuses on gender diversity's role inside organizations, emphasizing both its positive effect on innovative capacity and breadth of knowledge and its negative effect on social cohesion (e.g., Ali, Kulik, and Metz 2011; Cox 1994; Dwyer, Richard, and Chadwick 2003; Frink et al. 2003; Herring 2009; Richard et al. 2004; Richard, Ford, and Ismail 2006; Yang and Konrad 2011). Despite the many studies using these two approaches, empirical evidence has been mixed, with some studies finding a positive association between gender diversity and future performance and others finding a negative or null association (Post and Byron 2015). It therefore remains largely unclear how gender diversity relates to a firm's performance.

But previous research has paid little attention to the broader social context. This is an unfortunate oversight given the ways that societal norms and rules can influence how people approach diversity (Joshi and Roh 2009; Shore et al. 2009). In fact, institutional theory has long suggested that the institutional environment determines how workers, managers, and other stakeholders interpret and evaluate an organization's practices and structures (DiMaggio and Powell 1983; Meyer and Rowan 1977; Powell and DiMaggio 2012; Scott 1987; Suchman 1995; Zucker 1987). ${ }^{1}$ Accounting for institutional context in the study of the diversity-performance relationship may afford important insights (Konrad, Yang, and Maurer 2016; Yang and Konrad 2011).

I therefore propose that the relationship between gender diversity and firm performance - the latter measured by market valuation and firm revenue - depends on the acceptance of gender diversity in

\footnotetext{
1 There are several alternative names for institutional environment (DiMaggio and Powell 1983), including organizational field (Scott 1991), institutional field (Meyer and Rowan 1977), societal sector (Scott and Meyer 1982), and institutional sphere.
} 
the institutional environment. I distinguish between normative and regulatory institutions, defining normative legitimacy as the acceptance of a practice as appropriate and desirable based on shared organizational norms and values and regulatory legitimacy as the endorsement of a practice by regulators. I propose that both types moderate the association between gender diversity and firm performance and examine this proposition using a unique panel dataset of 1,069 leading public firms from 35 countries and 24 industries.

\section{GENDER DIVERSITY AND FIRM PERFORMANCE}

There are two broad approaches to understanding the relationship between gender diversity and firm performance. One considers the influence of gender diversity on external evaluators' perceptions of a firm, focusing on outcomes such as organizational reputation, image, and market valuation. A second approach considers gender diversity's influences on workers and managers, focusing on outcomes related to productivity and revenue. While the two approaches focus on different processes, I suggest that they could be similarly moderated by normative and regulatory environments.

\section{Market Valuation}

A firm's gender diversity can be an important criterion for potential investors (Lee and James 2007; Smith and Gaughan 2016). The rise of shareholder activism has encouraged more investors to become attentive to employment practices and has pushed more firms to disclose diversity numbers in their annual reports (Dobbin and Jung 2011; Hirsh and Cha 2015). As a number of studies have suggested, gender diversity can appeal to investors and benefit a firm's market valuation because it is seen as important for a firm's long-term growth and because it signals a firm's commitment to progressive gender values and attention to regulatory risks (Lamkin Broome and Krawiec 2008; Roberson and Park 2007; Wright et al. 1995). For example, studies find that firms ranked high on Fortune's diversity ranking tend to have higher market values, as do firms with more women in managerial positions (Carter, Simkins, and Simpson 2003; Dezsö and Ross 2012; Roberson and Park 2007). 
Similarly, firms typically experience a jump in stock price after winning an award related to diversity initiatives (Hannon and Milkovich 1996; Wright et al. 1995).

But other studies suggest that due to gender stereotyping, organizations with women in leadership roles may experience negative market reactions. Ahern and Dittmar (2012) find an immediate stock price drop following the announcement of a boardroom gender quota in Norway and find lower market valuation for affected firms in subsequent years. Some studies also find a negative market reaction to the appointment of women directors and CEOs (Dobbin and Jung 2011; Lee and James 2007).

The relationship between gender diversity and market valuation may be contingent on the social context. Norms and rules can shape investors' awareness of and preference for gender diversity and there is indeed a wide variation in attitudes toward gender diversity across national and industrial contexts (Jonsen, Maznevski, and Schneider 2011; Nishii and Özbilgin 2007). The intent of this study, which samples firms from across a variety of social contexts, is to provide a better understanding of the circumstances in which gender diversity is positively associated with market valuation.

\section{Firm Revenue}

A rich body of work has explored how gender diversity relates to a firm's productivity and revenue. Related literatures differ in the level of analysis: some focus on gender diversity in small groups within a firm and others on a firm's entire workforce (for reviews of group diversity, see Joshi and Roh 2009; Van Knippenberg and Schippers 2007; Williams and O'Reilly III 1998; for a review of board diversity, see Hoobler et al. 2016; Jeong and Harrison 2017; Post and Byron 2015; for a review of workforce diversity, see McMahon 2010). This study focuses on a firm's overall gender diversity, although it draws key insights from group-level studies.

There are two dominant perspectives on how gender diversity influences revenue. The resourcebased view considers diversity a valuable human resource that can increase a firm's productivity, creative capacity, and strategic decisions by increasing the range of available skills, perspectives, knowledge, and social networks (Cox 1994; DiTomaso, Post, and Parks-Yancy 2007). A number of studies find that firms 
with gender-diverse workforces innovate better and thus achieve higher output and returns (Ali, Kulik, and Metz 2011; Herring 2009; Richard et al. 2004; Yang and Konrad 2011).

An opposite perspective posits that diversity hurts productivity and revenue by lowering group commitment and cohesion. Drawing from a combination of social categorization theory (Tajfel 1981), social identity theory (Turner et al. 1987), and the similarity-attraction paradigm (Byrne 1971), this perspective suggests that, in gender-diverse groups, people are more likely to make favorable associations with ingroup members (those of their same gender) than with outgroup members (those of another gender). This can lead to conflict and stereotyping and hinder group solidarity and cooperation, thus reducing efficiency (Coffman 2014; Cox 1994; DiTomaso, Post, and Parks-Yancy 2007; Tsui, Egan, and O’Reilly III 1992; Van Knippenberg and Schippers 2007). Studies supporting this perspective find that gender diversity is associated with less productivity and lower efficiency (Ahern and Dittmar 2012; Matsa and Miller 2013; Richard et al. 2004).

It seems, then, that gender diversity could be a double-edged sword, bringing performance gains to some firms and losses to others. To fully understand this process, we must identify conditions that lead to one outcome rather than the other (Joshi and Roh 2009; Van Knippenberg and Schippers 2007). Research has mostly examined group-level moderators, focusing on characteristics related to group interdependence and task type. But the broader social context could also be influential. People's perceptions of and attitudes about gender could shape how they interact in gender-diverse settings, and these perceptions and attitudes are usually influenced by social norms at a societal level (Cox 1994).

In sum, the literature has developed several theoretical mechanisms by which gender diversity can influence a firm's valuation and revenue, but they are often at odds with one another. Institutional theory offers a framework that explains how norms and rules influence organizational behavior and its consequences (DiMaggio and Powell 1983; Meyer and Rowan 1977). In the following, I suggest that incorporating this broader social context may help resolve these conflicting perspectives. 


\section{AN INSTITUTIONAL APPROACH}

Institutional theory suggests that organizations are located within institutional environments, defined as "the communities of organizations that share a common meaning system" (Scott 1995: 56). Norms and rules in an institutional environment have important consequences for organizations and their stakeholders, helping shape what organizational practices are considered legitimate (DiMaggio and Powell 1983; Ingram and Silverman 2002; Meyer and Rowan 1977). Legitimacy is the general assumption that a practice is desirable, proper, or appropriate within some socially constructed system of rules, norms, and values (Suchman 1995).

I focus on two broad types of legitimacy: normative and regulatory (Archibald 2004). Regulatory legitimacy refers to institutional processes based on monitoring, rule-setting, and sanctioning. A practice gains regulatory legitimacy when regulators support it, usually through policies and standards. Normative legitimacy has both social and cognitive dimensions. A practice gains normative legitimacy when it is accepted as appropriate and desirable based on norms and values that are widely shared in the larger society (Aldrich and Fiol 1994; Archibald 2004; Zimmerman and Zeitz 2002). This definition of normative legitimacy is broader than that used in some studies, where normative institutions are equated with the particular ethics and worldviews of formal professions (e.g., DiMaggio and Powell 1983; Scott 1995). I use the more comprehensive definition to include the norms, values, and cultural cognitions of the broader institutional environment, including but not limited to professions (Archibald 2004; Deephouse and Suchman 2008; Suchman 1995).

Normative and regulatory legitimacy may interact and reinforce each other. Norms and values can influence regulators' perceptions of a practice and the content or enforcement of laws and policies. Similarly, regulatory frameworks can enact and transmit norms and values for organizations (Archibald 2004; Deephouse and Suchman 2008; Dobbin and Kelly 2007; Edelman 1992; Edelman, Fuller, and Mara-Drita 2001; Kelly and Dobbin 1998). Despite their reinforcing relationship, normative and regulatory legitimacy are distinct institutional forces and, as I propose below, they may interact with gender diversity through different mechanisms. 


\section{Normative Legitimacy}

Investors generally find it difficult to assess the value of a firm's gender diversity. Facing uncertainty, their perceptions are often shaped by the institutional environment's norms on how organizations should behave (Huang 2018; Zajac and Westphal 2004). They tend to value normatively accepted practices - which may or may not confer any actual performance benefit - and to penalize those outside the normative expectation (Westphal and Zajac 1998; Zajac and Westphal 2004; Zuckerman 1999). Therefore, in environments in which gender diversity is normatively accepted, investors should be more likely to perceive it as beneficial to a firm's future performance. In addition, investors, as speculators, care about other investors' behavior (Zajac and Westphal 2004). When the benefit of gender

diversity is normatively accepted, investors may anticipate positive responses from other investors when a firm increases its gender diversity. In contrast, in contexts in which gender diversity has not gained normative acceptance, investors may see it as irrelevant or even detrimental to future performance.

When gender diversity is normatively accepted, it can also provide indirect benefits. Investors tend to see firms that follow normatively accepted practices as better managed than firms that do not (Zajac and Westphal 2004). Expecting firms to converge toward a norm, such as greater gender diversity, investors may view an increase in a firm's gender diversity as a signal of good management (Welbourne, Cycyota, and Ferrante 2007). But when gender diversity is not normatively accepted, investors may not expect firms to promote it and may not see an increase as a positive signal.

Hypothesis 1 (H1): The normative legitimacy of gender diversity positively moderates the relationship between a firm's gender diversity and its subsequent market valuation. Specifically, gender diversity is more positively related to market valuation in contexts in which it has more normative acceptance.

Normative legitimacy may also moderate the relationship between gender diversity and firm revenue. First, the role of gender diversity in generating a wide variety of knowledge-based resources and 
innovative solutions may itself be contingent on its normative acceptance. When gender diversity is normatively accepted, workers and managers are more likely to value it in the workplace (Bilimoria 2006). This attitude is important in facilitating open and explicit discussion of different perspectives and integrating diverse knowledge and solutions to improve organizational effectiveness (Thomas and Ely 1996; Van Knippenberg and Schippers 2007), which can help the firm appeal to a wider range of customers and generate better strategies and solutions (Ali, Kulik, and Metz 2011; Cox 1994; Joshi and Roh 2009). This is particularly important in high-tech sectors, in which technical innovation is critical, and in service industries, in which marketing innovation can create competitive advantage (Joshi and Roh 2009). In contrast, when gender diversity is not valued, workgroup interactions tend to lack cross-cultural learning and women often cannot bring their unique skills and insights to bear (Ely and Thomas 2001; Lee and Huang 2018).

Second, the normative legitimacy of gender diversity can moderate social categorization. When gender diversity is widely embraced, the exchange of different perspectives and knowledge creates a sense of inclusion and makes women employees feel respected and valued for their contributions (Ely and Thomas 2001; Van Knippenberg, Haslam, and Platow 2007). It also facilitates healthy interactions in the workplace, reducing the likelihood of discrimination and conflict (Van Knippenberg, van Ginkel, and Homan 2013; Van Knippenberg and Schippers 2007; Zhang 2017). When gender diversity is not valued, however, women tend to experience more gender stereotyping, which could lead them to feel less attachment to the organization (Ely and Thomas 2001; Van Knippenberg, Haslam, and Platow 2007). That, in turn, undermines social cohesion, which is an important determinant of firm productivity; employees work harder and cooperate more effectively when they feel a stronger attachment to the firm (Ely and Thomas 2001; Richard, Ford, and Ismail 2006; Van Knippenberg and Schippers 2007).

Hypothesis 2 (H2): The normative legitimacy of gender diversity positively moderates the relationship between a firm's gender diversity and its subsequent revenue. Specifically, gender diversity is more positively related to firm revenue in contexts in which it has more normative acceptance. 


\section{Regulatory Legitimacy}

Firms that do not follow state diversity regulations such as anti-discrimination and affirmativeaction policies can suffer substantial reputational loss in addition to fines (Hirsh and Cha 2015; James and Wooten 2004). Studies have found that firms suffer an average 15.6 percent drop in market value after a diversity lawsuit (Hersch 1991; James and Wooten 2004). In Norway, when the boardroom gender quota law was introduced, firms with women on their boards experienced significantly more positive market reactions than firms without (Ahern and Dittmar 2012). These studies suggest that investors are highly attentive to a firm's conformity to diversity regulations and that any indication of violation may lead investors to preventively withdraw investments.

In practice, because it is difficult to directly assess a firm's conformity to diversity regulations, a firm's diversity figures often become an important indicator (Edelman 1992; Hirsh and Kornrich 2008). For example, equal employment opportunity (EEO) investigators in the United States frequently use workplace composition data to determine if a firm has used ascription in hiring and opportunity allocation (Hirsh and Kornrich 2008). In institutional contexts where diversity laws are in effect, investors are more likely to use a firm's gender diversity numbers as an indicator of litigation risk.

Hypothesis 3 (H3): The regulatory legitimacy of gender diversity positively moderates the relationship between a firm's gender diversity and its subsequent market valuation. Specifically, gender diversity is more positively related to market valuation in contexts in which it has more regulatory acceptance.

However, it is also possible that investors may not be influenced by the regulatory environment to the same extent that they are by the normative environment. Investors, overwhelmed with information, may not have the attention span to closely follow a firm's conformity to regulations. Although studies have shown negative market reactions to diversity lawsuits, such lawsuits are rare and often receive inflammatory media coverage. In addition, when investors perceive a firm's gender diversity as merely a reaction to rules imposed by regulators, they could interpret it as mere symbolic "window dressing" and 
may even react negatively. Ahern and Dittmar (2012) show that increases in board gender diversity after the introduction of Norway's quota led to negative market reactions, largely because investors saw the newly appointed women directors as less competent than the existing directors, installed only to meet the quota. Therefore, there are reasons to believe that the moderating role of the regulatory environment may be insignificant.

Finally, gender diversity's regulatory legitimacy may also positively influence patterns of interaction among workers and managers inside a diverse firm, affecting its productivity and output. When regulators endorse diversity, people are more likely to see the presence of women in the workforce and in leadership positions as legitimate. For example, experiments show that when higher authorities institutionalize women's leadership, subjects are less likely to gender stereotype and are more likely to see women leaders as competent (Lucas 2003). As with the mechanisms underlying the construction of $\mathrm{H} 2$, I expect the regulatory acceptance of gender diversity to reduce gender stereotyping and encourage women to contribute their unique views and perspectives, which could increase productivity and improve decision making, leading to higher revenue for more gender-diverse firms.

Hypothesis 4 (H4): The regulatory legitimacy of gender diversity positively moderates the relationship between a firm's gender diversity and its subsequent revenue. Specifically, gender diversity is more positively related to firm revenue in contexts in which it has more regulatory acceptance.

There is also evidence that calls into question the positive influence of regulatory legitimacy. Affirmative action laws sometimes lead employees to perceive women as less competent, marginalizing them and reducing cross-group communication (e.g., Heilman, Block, and Stathatos 1997). And while diversity regulation can reduce open discrimination, it may also discourage people from openly confronting different perspectives and viewpoints. In a qualitative study, Ely and Thomas (2001) find that when workers and managers see diversity as prevention of discrimination rather than as a valuable asset, there tends to be less cross-group interaction and learning. That is, when workers see diversity as a result 
of regulatory compliance rather than a way to capitalize on an asset, it has a less positive impact on innovation and problem solving (Ely and Thomas 2001; Thomas and Ely 1996). Regulatory legitimacy may therefore have a minimal moderating influence on productivity and firm revenue.

\section{METHODS}

I examine the relationship between a firm's gender diversity and its subsequent performance across two types of institutional context: countries and industries (Thornton and Ocasio 2008). First, gender diversity regulation and norms are often country-specific. In most cases, the state is responsible for conferring regulatory legitimacy through employment regulations, and normative discourses on gender diversity also show significant cross-national variation (Wright et al. 1995). For example, both the national media and the general public can contribute to the emergence of country-specific gender diversity norms (Jonsen, Maznevski, and Schneider 2011). Cross-national studies have found that national context strongly shapes both the regulatory and the normative legitimacy of gender diversity in organizations (Klarsfeld 2010; Nishii and Özbilgin 2007).

Second, the normative and regulatory legitimacy of gender diversity can be industry-specific. Each industry has a unique set of task environments, so investors and workers may see the importance of gender diversity in some industries but not in others (Ali, Kulik, and Metz 2011; Joshi and Roh 2009). Organizations in an industry also share a common meaning system (Scott 1995; Scott and Meyer 1982) and each industry has its standards and professional norms, reinforced by industry-wide associations and by peer interactions, often at the global level (Arias and Guillen 1998; Wooten and Hoffman 2016). Thus, the normative and regulatory legitimacy of diversity should differ across industries.

This study examines leading firms across different countries and industries. Larger firms face stronger institutional pressure because they tend to attract more scrutiny from regulators, investors, media, and the general public. Greater scrutiny pushes many of them to regularly disclose workforce diversity numbers. These characteristics make these firms an ideal setting for examining how the institutional environment moderates investors', workers', and managers' approaches to gender diversity. 


\section{Data}

The sample includes leading public firms from 35 countries and 24 industries and spans from 2007 to 2014. I began with the S\&P Global Index, which represents the movement of the global stock market and is one of the most commonly used global indices (Hansen, Ibarra, and Peyer, 2013). It contains 1,200 leading public corporations, including 500 listed on US exchanges (S\&P 500 Index), 350 in Europe (S\&P 350 European Index), 150 in Japan, and 200 from the rest of the world. Because firms outside North America, Western Europe, and Japan are underrepresented, I supplemented the sample by drawing from the leading index in each of the following major markets: Australia (ASX 200 Index), Austria (VSE Austrian Traded Index), Brazil (Bovespa Index), China and Hong Kong (Hang Seng Index), Colombia (COLCAP Index), India (BSE Sensex Index), Indonesia (JSE LQ45 Index), Israel (Tel Aviv 25 Index), Malaysia (KLCI Index), Philippines (Philippines SE Index), Russia (MICEX Index), Singapore (FTSE Straits Times Index), South Africa (BSE Sensex 30 Index), South Korea (KOSPI 50 Index), and Thailand (Thai SET 50 Index). Nine countries and regions have fewer than five firms in the sample: Bermuda, Jersey, Jordan, Luxembourg, Macau, Malta, Panama, Peru, and Portugal. Because so few observations may not offer good representation, I excluded firms headquartered in these countries from the analysis, leaving 1,703 firms in 35 countries and 24 industries. I classified industries according to the Global Industry Classification Standard (GICS), widely used internationally (Bhojraj, Lee, and Oler 2003).

I gathered gender composition and financial data on each firm from Bloomberg, a widely used financial database that provides company profiles and financial statements (Yan, Ferraro, and Almandoz 2018). Bloomberg collects workforce diversity information from firms' annual reports. An increasing number of firms are reporting workforce gender composition annually as part of disclosure on corporate social responsibility. Many of these reports help investors learn not only a firm's current gender diversity, but also how it compares to previous years. For example, Google's 2015 CSR report states: “31\% of our employees were women, a 1\% increase from last year." Out of the 1,703 firms, 1,069(63\%) have 
disclosed their workforce gender composition through such reports and have, on average, 4.7 years of observations between 2007 and 2014. Most of the firms missing this information are headquartered in Asia and North America. Selection bias could potentially confound the results; I therefore ran separate analyses on firms headquartered in Europe and Latin America, where selection bias is a relatively minor issue. Findings from this subsample are substantively similar to findings from the full sample.

Finally, while I used the country location of each firm's headquarters, it is possible that some firms focus heavily on an overseas market and are therefore also subject to a different set of institutional norms. I therefore obtained data from Bloomberg on firms' market distribution by geography and designated a firm as overseas-oriented if its largest geographical market segment is a country other than its headquarters country. Of my sample, 202 firms (19\%) are categorized as overseas-oriented. I ran a robustness check by grouping these firms into a separate country category in calculating normative legitimacy; this does not substantively change the results.

Table 1 gives a detailed breakdown of the sample by country and industry.

[Insert Table 1 here]

\section{Analytic Strategy}

I used linear regression models with fixed effects on firms and on country-year dyads to explore patterns between gender diversity and firm performance across different contexts. A firm-fixed-effects model accounts for unobserved time-invariant firm characteristics. In this sample, 5.8 percent of the firms have a single observation and are therefore dropped in firm-fixed-effects models. The average sample firm has a 9-percent change in the number of female workers, suggesting at least some within-firm variation in gender composition during the study period.

Likewise, I included country-by-year dyadic fixed effects to account for country-level changes each year, since a firm's stock price and revenue can be driven by a country's economic growth. The inclusion of country-year-dyad fixed effects controls for country-level differences among firms, eliminating the need for other country-level controls in the model. 
While the large number of parameters used in fixed-effects models makes them less efficient than random-effects models, they provide more stringent tests of hypotheses (Halaby 2004). As an alternate assessment, I also performed analyses using firm random-effects models. Because fixed effects cannot account for time-varying within-cluster correlation, I clustered standard errors at the firm level.

\section{Measures of Firm Performance}

I used two measures of firm performance as the dependent variables: Tobin's Q and return on assets (ROA). Tobin's Q is calculated as a firm's market value over the replacement value of its assets. Because investors determine the market value, Tobin's Q directly measures the market's perception of a firm's long-term value. ROA measures actual return without taking into account stock market speculations. As Table 2 shows, the two measures are correlated at 0.5. Because ROA can influence market valuation, I include it as a control in models predicting Tobin's Q.

\section{Gender Diversity Measure}

To measure a firm's gender diversity in a given year, I used the conventional Blau's index (e.g., Ali, Kulik, and Metz 2011; Richard et al. 2004): Gender diversity $=1-(\text { pct women workers })^{\wedge} 2-(p c t$ men workers $)^{\wedge} 2$. The resulting variable ranges from 0 to 0.5 , with a higher value indicating greater gender diversity. I lagged measures of gender diversity by one year. As a robustness check, I replaced Blau's index with the percent of female employees in a firm. The two measures are highly correlated (cor=0.8) and the resulting models are substantively similar.

\section{Measures of Normative and Regulatory Legitimacy}

I measured the normative legitimacy of gender diversity using two methods. The first is the prevalence of women on boards of directors in each country and industry. Having women in important and visible positions signals that organizations value gender diversity and see the presence of women in their workforces as appropriate and desirable (Lamkin Broome and Krawiec 2008; Dezso, Ross, and 
Uribe 2016; Dobbin and Jung 2011; Skaggs, Stainback, and Duncan 2012). For example, cross-national analyses found that the prevalence of women on boards in a country is strongly correlated with various other proxies of that country's diversity norms (Grosvold 2011).

Because the main sample is biased toward larger firms, I gathered a more representative sample in each country and industry to measure the prevalence of women on boards. The S\&P Global Broad Market Index is one of the broadest and most representative stock indices, covering 11,000 large-, middle-, and small-cap firms worldwide. Bloomberg offers annual data on board composition for over 80 percent of the firms in the Broad Market Index..$^{2}$ Using this more representative sample, I constructed normative legitimacy based on the average percentage of women board members in a country or industry.

The second measure of normative legitimacy is the percentage of firms in a country or industry that have publicly announced pro-diversity policies or programs. Past studies suggest that organizations' public commitment to diversity reflects its normative legitimacy in the institutional environment (Dobbin, Kim, and Kalev 2011; Edelman 1992). Every year, Bloomberg tracks over 8,000 firms in the Broad Market Index on whether or not they have announced, through press releases or investors' reports, a commitment to increase diversity, ensure equal employment, promote affirmative action, or otherwise support diversity. The two measures of normative legitimacy are moderately correlated $(0.5$ at the country level and 0.4 at the industry level).

To measure regulatory legitimacy, I used the Women, Business and the Law database provided by the World Bank Group to examine each country's legal environment for women in the workplace. Since 2010, the World Bank Group has issued biannual reports that measure gender inequality in the law for over 140 countries. These reports are compiled by a team of experienced lawyers and legal experts who use a consistent set of metrics across countries in evaluating legal frameworks to "ensure data comparability" (World Bank Group 2016). A section of the report focuses on the regulatory environment for women in the workplace, including laws on maternity and parental leave, nondiscrimination and equal

\footnotetext{
2 The Bloomberg database has much more complete coverage for board data than for workforce data. For most of the 11,000 firms in the Broad Market Index, Bloomberg provides board data but not workforce data. Hence, I use the Broad Market Index only to measure normative legitimacy in each country and industry.
} 
remuneration, retirement age, and legal restrictions to certain occupations and tasks. Using this

information, I assigned each country a score, which I used as the measure of the regulatory legitimacy of gender diversity in each country-year. Appendix 1 includes more details on the construction of this variable.

As discussed earlier, normative and regulatory legitimacy may influence each other. Not surprisingly, in my sample of countries, the regulatory-legitimacy measure and the two normativelegitimacy measures have positive correlations ( 0.2 and 0.3 at the country-year level). But as Figure 1 shows, some countries rank high in one type of legitimacy but not in the other, suggesting considerable distinctions between the two types. For example, both Japan and South Korea have strong regulatory support for women in the workplace, but weak normative acceptance of gender diversity.

\section{[Insert Figure 1 here]}

\section{Controls}

I included the following time-varying firm-level variables, collected from Bloomberg: number of employees, percentage of employee turnover, whether or not a firm has a diversity policy, and percentage of women board members (Dobbin and Jung 2011). The number of employees accounts for a firm's size and the percentage of turnover controls for possible firm downsizing, both of which may influence performance. At the country level, I included a country's gender wage gap, female-to-male ratio for years of schooling, and GDP per capita and interacted them with gender diversity as additional controls. Data for these variables come from the Organisation for Economic Co-operation and Development (OECD) and the International Labour Organization (ILO), among other sources. ${ }^{3}$ Gender wage gap and female-tomale ratio for years of schooling help capture gender differences in human capital and workplace hierarchy, which could confound the performance effect of gender diversity. It is worth noting that although wage and education gender gaps could reflect a country's institutional environment, they are

\footnotetext{
3 The main data source on gender wage gap and on educational attainment by gender come from OECD and ILO. For countries not included in these two databases, I draw data from wageindicator.org, the United Nations Economic Commission for Europe (UNECE), United Nations Human Development Reports, and World DataBank from the World Bank Group.
} 
also influenced by other factors and are only weakly correlated with a country's normative and regulatory acceptance of gender diversity (at the country-year level, none of the correlations surpasses 0.2). Finally, at the industry level, I adopted Joshi and Roh's (2009: 613) criteria and categorized each firm as manufacturing, service, or high-tech based on its main industry, then interacted gender diversity with the firm's industry type to account for differences in industry activities. I also controlled for each industry's gender segregation and interacted it with gender diversity to consider the possibility that gender diversity may embody different meanings in highly segregated industries and in industries with no segregation. I obtained each industry's level of gender segregation from Cartwright, Edwards, and Wang (2011), who constructed these values based on data from the US.

[Insert Table 2 here]

\section{RESULTS}

Results suggest that the more gender diversity has been normative accepted, the more it positively relates to subsequent market valuation and firm revenue. Table 3 uses linear models with firm fixed effects on the entire sample. Table 4 includes additional variables to account for alternative explanations. Table 5 includes lagged dependent variables because a firm's past performance could influence its future performance. Table 6 uses firm random effects instead of fixed effects to give between-firm comparisons.

Table 3 uses firm fixed effects. Models 1 and 6 examine the correlation between a firm's gender diversity and its subsequent ROA and Tobin's Q. Gender diversity by itself has no statistically significant correlation with either revenue or market valuation, a result mostly consistent with previous studies (Ali, Kulik, and Metz 2011; Richard, Ford, and Ismail 2006). But normative and regulatory legitimacy in the institutional environment have significant moderating influences. Models 2 through 5 show that all measures of normative legitimacy, at both the country and industry levels, positively moderate the correlation between gender diversity and ROA. Models 3 and 4 include a country's regulatory legitimacy, which also positively moderates the relationship between gender diversity and ROA. Models 7 through 10 use Tobin's Q as the measure of firm performance and show a similar pattern. Normative and regulatory 
legitimacy of gender diversity, at both the country and the industry levels, positively moderate the correlation between gender diversity and Tobin's Q. When a country has high normative and regulatory legitimacy of gender diversity (1 SD above the mean), an increase in a firm's gender diversity has a statistically significant positive correlation with both future ROA ( $b=14.7)$ and future Tobin's $Q(b=0.69)$. However, when the firm is in a country with low normative and regulatory legitimacy of gender diversity (1 SD below the mean), the same increase in gender diversity is negatively associated with future ROA $(b=-29.2)$ and future Tobin's $Q(b=-0.89)$. A similar pattern occurs across industries. It is worth noting that models predicting Tobin's Q control for ROA, so the observed effects are due to investors' perceptions of a firm's future value beyond its current revenue. Overall, Table 3 is consistent with the hypotheses that both normative and regulatory acceptance positively moderate the association between gender diversity and firm performance.

[Insert Table 3 here]

Table 4 includes interactions between gender diversity and additional country- and industry-level variables to account for possible confounders. First, countries vary in their gender wage gaps (Wright, Baxter, and Birkelund 1995). In some less-liberalized markets, gender diversity may simply be a way to lower costs, rather than reflecting an institutional norm (Klarsfeld 2010). To account for this possibility, I included the interaction between gender diversity and the country's gender wage gap. A second possibility is that cross-national differences in human-capital gender gaps may contribute to the findings in Table 3. It is possible that countries that have legitimized gender diversity in the workplace also have smaller human-capital gender gaps. I addressed this possibility by including the interaction between gender diversity and female-to-male years of schooling ratio. Third, a country's economic development may also moderate the impact of gender diversity on performance (Klarsfeld 2010). I used a country's annual logged GDP as a control and interacted it with gender diversity in Table 4. Fourth, past research has argued that the effect of organizational diversity may differ between technology, service, and manufacturing industries (Ali, Kulik, and Metz 2011; Joshi and Roh 2009). Table 4 controls for the interaction between gender diversity and industry type. Fifth, research has shown significant cross- 
industrial differences in patterns of gender segregation (Wharton and Baron 1987). It is possible that in highly gender-segregated industries there is little opportunity for cross-gender interaction and hence gender diversity has little meaning to firms, workers, and investors. I therefore controlled for the interaction between gender diversity and industry-level gender segregation. Most of these additional interaction terms do not significantly moderate the relationship between gender diversity and performance, with the exception of industry type. Gender diversity tends to be more positively associated with subsequent performance in service industries, as is evident in Models 2, 4, and 7. This is presumably because service industries require more customer interaction, innovation, and problem solving, all of which could benefit from gender diversity. Gender diversity also has a more positive correlation with Tobin's Q in high-technology industries, but surprisingly, a more negative correlation with ROA. High tech industries require more creativity and innovation, so they should benefit more from gender diversity. The negative correlation with ROA in technology industries are inconsistent with theoretical expectations, but consistent with previous empirical findings (Joshi and Roh 2009).

For the purpose of examining the main hypotheses, including these additional interaction terms in Table 4 does not substantively change the findings. Consistent with Table 3, both normative and regulatory legitimacy moderate the relationship between gender diversity and performance.

\section{[Insert Table 4 here]}

Table 5 includes lagged dependent variables. A firm's past performance could influence its subsequent engagement with diversity and inclusion (Zhang 2018). I used Arellano-Bover linear dynamic panel-data estimation, which uses an instrument approach and is designed for datasets with many panels and few periods (Blundell and Bond 1998). This approach produces some results that are consistent with the findings in Table 3 and a few that are notably different. First, consistent with the previous models, an industry's normative acceptance of gender diversity positively moderates the correlation between gender diversity and both ROA and Tobin's Q, as shown in Models 3, 5, 8, and 10. Second, a country's normative acceptance shows a positive moderating influence when measured as the percentage of firms with diversity policies (Models 4 and 9), but not when measured as the average percentage of women 
board members (Models 2 and 7). Third, a country's regulatory environment no longer shows a significant moderating influence (Models 4 and 9). Overall, these models provide evidence that gender diversity's normative legitimacy positively moderates its relationship with performance, but its regulatory legitimacy does not.

Finally, Table 6 uses random effects instead of fixed effects at the firm level. In predicting ROA, Models 1 through 5 show findings consistent with those in Table 3. Both normative and regulatory environments positively moderate the relationship between gender diversity on ROA. In predicting Tobin's Q, normative legitimacy positively moderates the relationship of gender diversity when measured as the percentage of firms with diversity policies, but this moderation effect becomes null when using the average percentage of women board members to measure the normative environment. In Models 7 and 9, regulatory environment does not have a significant influence on how gender diversity is related to Tobin's Q.

[Insert Table 6 here]

In sum, there is fairly strong evidence that gender diversity's normative acceptance in the environment positively moderates its relationship with both firm revenue and market valuation (H1 and $\mathrm{H} 2$ ), but only weak evidence that its regulatory acceptance has such a moderating role (H3 and H4).

\section{CONCLUSION}

What is the relationship between a firm's gender diversity and its subsequent performance? I suggest that the answer depends on the institutional context. Using a unique longitudinal dataset of 1,069 firms in 35 countries and 24 industries, I show that the more gender diversity is normatively accepted in a country or industry, the more it is positively correlated with a firm's subsequent market valuation and revenue.

This study uses institutional theory to explain the relationship between gender diversity and firm performance. In recent years, a rich literature has emerged on gender diversity and performance, but has produced highly inconsistent predictions and findings: some propose and find a positive association between gender diversity and subsequent performance, while others show a negative or null association. 
As recent review articles and meta-studies have pointed out, it appears that gender diversity could benefit performance in some settings and harm it in others, and that the conditions that moderate its effect need more exploration (Joshi and Roh 2009; Post and Byron 2015). In identifying these conditions, most studies have focused on group-level moderators. This study shifts the focus to macro-level contexts by examining cross-national and cross-industrial variations. Social norms and regulations could influence how investors, workers, and managers perceive and approach gender diversity. For instance, in some countries and industries, gender diversity is considered a valuable asset that can improve productivity and decision making, so investors may prefer gender-diverse firms and employees may approach gender diversity positively. Where gender diversity is not valued, investors may see it as detrimental to firms' future performance and women employees may experience more discrimination and stereotyping, diminishing their ability to contribute to firm performance. Thus, the institutional environment shapes people's attitudes and approaches toward gender diversity and moderates its relationship with performance.

In investigating the institutional context, this study differentiates between normative and regulatory environments. Across most models, normative legitimacy of gender diversity has a significant and positive moderating role on the relationship between gender diversity and firm performance, suggesting that societal norms are important in shaping how investors, workers, and managers approach gender diversity. Regulatory legitimacy of gender diversity shows a significant moderating role in some models, but not in others. It is possible that the regulatory environment has less influence on investors, workers, and managers than the normative environment does. When people see diversity as a regulatory requirement and do not accept its value, they may simply ignore it or even approach it negatively. Hence, gender diversity may not benefit a firm when it has been accepted by regulators but not by societal norms. This possible distinction between normative and regulatory institutions can help us better understand the workings of various types of institutional forces (Aldrich and Fiol 1994; Archibald 2004; Deephouse and Suchman 2008; Scott 1995; Zimmerman and Zeitz 2002). 
While the results draw out a possible distinction between normative and regulatory institutions, I also recognize their influence on each other. In particular, regulations can help shape organizational actors' perceptions of the appropriate norms for their organizations; for example, the Equal Employment Opportunity law in the US led to the emergence of diversity experts whose advocacy over time promoted the normative acceptance of diversity (Dobbin and Kelly 2007; Edelman 1992; Kelly and Dobbin 1998). In this study, a country's employment laws on gender may influence its firms' willingness to hire women directors and adopt diversity policies and vice versa, as evident from the positive correlation between these measures. Future research should explore this interplay between normative and regulatory forces in the broader institutional environment.

In terms of design, the cross-national sample used in this study offers a unique opportunity to explore diversity issues globally. Research on gender diversity and performance has tended to focus on the United States and other Western countries (Jonsen, Maznevski, and Schneider 2011; Nishii and Özbilgin 2007). This study shows important cross-national differences in how gender diversity relates to performance. Given the generally greater acceptance of gender diversity in Western countries, the benefit of gender diversity should be more readily visible there than in Asia, Latin America, the Middle East, and Africa. These important cross-national differences imply that research findings from the United States and Europe cannot be directly extrapolated to non-Western countries and suggest that future studies should further examine gender diversity and firm performance in non-Western contexts.

This study has limitations. First, the focus on leading firms may create generalizability issues. While leading firms offer an advantageous study setting because of their greater connection to the institutional environment, institutional influence may be less salient in smaller firms. Second, while this study examines gender diversity in the general workforce, a separate literature has focused on diversity in top management teams (Jeong and Harrison 2017; Post and Byron 2015). Workforce diversity and top management diversity have important distinctions (Richard 2000), so it is not clear whether the institutional influences hypothesized here apply to top management teams. This could be an interesting direction for future research. 
Going forward, it will be worthwhile to further explore the role of the broader social context in determining how gender diversity relates to firm outcomes. The value of gender diversity can be socially constructed; how people perceive and approach it depends on the broader normative environment. The more people accept gender diversity, the more they will embrace it and the more it can benefit an organization. For this reason, analysis of gender diversity and firm outcomes should pay close attention to the social context. A fruitful future research direction will be to continue using a cross-industrial and cross-country design to identify further contextual variations in the relationship between gender diversity and firm performance. In addition, while this study focuses on gender diversity, the institutional environment may also affect the way we perceive minority managers and workers; thus, it will be important to explore how institutional contexts moderate the other forms of diversity, such as race, ethnicity, and nationality.

In conclusion, as women continue to make progress in the workplace, understanding the association between gender diversity and firm performance has significant implications for both practitioners and researchers. Using a cross-national and cross-industrial design, this study underscores the importance of institutional norms and encourages future research to account for broader social contexts in understanding the link between gender diversity and performance. 


\section{REFERENCES}

Ahern, Kenneth R., and Amy K. Dittmar. 2012. "The Changing of the Boards: The Impact on Firm Valuation of Mandated Female Board Representation." Quarterly Journal of Economics 127 (1): 137-197.

Aldrich, Howard E., and C. Marlene Fiol. 1994. "Fools Rush In? The Institutional Context of Industry Creation." Academy of Management Review 19 (4): 645-670.

Ali, Muhammad, Carol T. Kulik, and Isabel Metz. 2011. "The Gender Diversity-Performance Relationship in Services and Manufacturing Organizations." International Journal of Human Resource Management 22 (07): 1464-1485.

Archibald, Matthew E. 2004. "Between Isomorphism and Market Partitioning: How Organizational Competencies and Resources Foster Cultural and Sociopolitical Legitimacy, and Promote Organizational Survival." In Cathryn Johnson (eds.), Legitimacy Processes in Organizations, 171-211. Bingley: Emerald Group.

Arias, Maria Eugenia, and Mauro Guillen. 1998. "The Transfer of Organizational Techniques across Borders: Combining Neo-Institutional and Comparative Perspectives." In Alvarez, Jose Luis (eds.), The Diffusion and Consumption of Business Knowledge, 110137. London: Palgrave Macmillan.

Bhojraj, Sanjeev, Charles Lee, and Derek K. Oler. 2003. "What's My Line? A Comparison of Industry Classification Schemes for Capital Market Research." Journal of Accounting Research 41 (5): 745-774.

Bilimoria, Diana. 2006. "The Relationship between Women Corporate Directors and Women Corporate Officers." Journal of Managerial Issues 18 (1): 47-61.

Blundell, Richard, and Stephen Bond. 1998. "Initial Conditions and Moment Restrictions in Dynamic Panel Data Models.” Journal of Econometrics 87 (1): 115-143.

Byrne, Donn Erwin. 1971. The Attraction Paradigm. Vol. 11. New York: Academic Press.

Carter, David A., Betty J. Simkins, and W. Gary Simpson. 2003. "Corporate Governance, Board Diversity, and Firm Value." Financial Review 38 (1): 33-53.

Cartwright, Bliss, Patrick Ronald Edwards, and Qi Wang. 2011. "Job and Industry Gender Segregation: NAICS Categories and EEO-1 Job Groups.” Monthly Labor Review 134 (11): 37-50.

Coffman, Katherine Baldiga. 2014. "Evidence on Self-Stereotyping and the Contribution of Ideas." Quarterly Journal of Economics 129 (4): 1625-1660.

Cox, Taylor. 1994. Cultural Diversity in Organizations: Theory, Research and Practice. Oakland: Berrett-Koehler.

Deephouse, David L., and Mark Suchman. 2008. "Legitimacy in Organizational Institutionalism." In Royston Greenwood, Christine Oliver, Roy Suddaby, Kerstin Sahlin (eds.), The Sage Handbook of Organizational Institutionalism 49-77. Los Angeles: Sage.

Dezsö, Cristian L., and David Gaddis Ross. 2012. "Does Female Representation in Top Management Improve Firm Performance? A Panel Data Investigation.” Strategic Management Journal 33 (9): 1072-1089.

Dezsö, Cristian L., David Gaddis Ross, and Jose Uribe. 2016. "Is There an Implicit Quota on Women in Top Management? A Large-Sample Statistical Analysis.” Strategic Management Journal 37 (1): 98-115. 
DiMaggio, P. J., and W. W. Powell. 1983. "The Iron Cage Revisited: Institutional Isomorphism and Collective Rationality in Organizational Fields." American Sociological Review 48 (2): 147-160.

DiTomaso, Nancy, Corinne Post, and Rochelle Parks-Yancy. 2007. "Workforce Diversity and Inequality: Power, Status, and Numbers." Annual Review of Sociology 33: 473-501.

Dobbin, Frank, and Jiwook Jung. 2011. "Corporate Board Gender Diversity and Stock Performance: The Competence Gap or Institutional Investor Bias?" North Carolina Law Review 89 (3): 809-839.

Dobbin, Frank, and Erin L. Kelly. 2007. "How to Stop Harassment: Professional Construction of Legal Compliance in Organizations." American Journal of Sociology 112 (4): 1203-1243.

Dobbin, Frank, Soohan Kim, and Alexandra Kalev. 2011. "You Can't Always Get What You Need Organizational Determinants of Diversity Programs." American Sociological Review 76 (3): 386-411.

Dwyer, Sean, Orlando C. Richard, and Ken Chadwick. 2003. “Gender Diversity in Management and Firm Performance: The Influence of Growth Orientation and Organizational Culture." Journal of Business Research 56 (12): 1009-1019.

Edelman, Lauren B. 1992. "Legal Ambiguity and Symbolic Structures: Organizational Mediation of Civil Rights Law." American Journal of Sociology 97 (6): 1531-1576.

Edelman, Lauren B., Sally Riggs Fuller, and Iona Mara-Drita. 2001. "Diversity Rhetoric and the Managerialization of Law." American Journal of Sociology 106 (6): 1589-1641.

Ely, Robin J., and David A. Thomas. 2001. "Cultural Diversity at Work: The Effects of Diversity Perspectives on Work Group Processes and Outcomes." Administrative Science Quarterly 46 (2): 229-273.

Frink, Dwight D., Robert K. Robinson, Brian Reithel, Michelle M. Arthur, Anthony P. Ammeter, Gerald R. Ferris, David M. Kaplan, and Hubert S. Morrisette. 2003. "Gender Demography and Organization Performance: A Two-Study Investigation with Convergence." Group \& Organization Management 28 (1): 127-147.

Grosvold, Johanne. 2011. "Where Are All the Women? Institutional Context and the Prevalence of Women on the Corporate Board of Directors." Business \& Society 50 (3): 531-555.

Halaby, Charles N. 2004. "Panel Models in Sociological Research: Theory into Practice." Annual Review of Sociology 30: 507-544.

Hannon, John M., and George T. Milkovich. 1996. "The Effect of Human Resource Reputation Signals on Share Prices: An Event Study." Human Resource Management 35 (3): 405424.

Heilman, Madeline E., Caryn J. Block, and Peter Stathatos. 1997. "The Affirmative Action Stigma of Incompetence: Effects of Performance Information Ambiguity." Academy of Management Journal 40 (3): 603-625.

Herring, Cedric. 2009. "Does Diversity Pay? Race, Gender, and the Business Case for Diversity." American Sociological Review 74 (2): 208-224.

Hersch, Joni. 1991. "Equal Employment Opportunity Law and Firm Profitability." Journal of Human Resources 26 (1): 139-153.

Hirsh, Elizabeth, and Youngjoo Cha. 2015. "Employment Discrimination Lawsuits and Corporate Stock Prices." Social Currents 2 (1): 40-57. 
Hirsh, Elizabeth, and Sabino Kornrich. 2008. "The Context of Discrimination: Workplace Conditions, Institutional Environments, and Sex and Race Discrimination Charges." American Journal of Sociology 113 (5): 1394-1432.

Hoobler, Jenny M., Courtney R. Masterson, Stella M. Nkomo, and Eric J. Michel. 2016. "The Business Case for Women Leaders Meta-Analysis, Research Critique, and Path Forward." Journal of Management 44(6): 2473-2499.

Huang, Laura. 2018. "The Role of Investor Gut Feel in Managing Complexity and Extreme Risk." Academy of Management Journal 61 (5): 1821-1847.

Ingram, Paul, and Brian Silverman. 2002. The New Institutionalism in Strategic Management. Bingley: Emerald Group.

James, Erika Hayes, and Lynn Perry Wooten. 2004. "Restoring Reputation: Firm Response Strategies for Managing a Discrimination Crisis." Working Paper, Darden Business School, Charlottesville.

Jeong, Seung-Hwan, and David A. Harrison. 2017. "Glass Breaking, Strategy Making, and Value Creating: Meta-Analytic Outcomes of Women as CEOs and TMT Members." Academy of Management Journal 60 (4): 1219-1252.

Jonsen, Karsten, Martha L. Maznevski, and Susan C. Schneider. 2011. "Special Review Article: Diversity and Its Not So Diverse Literature: An International Perspective." International Journal of Cross Cultural Management 11 (1): 35-62.

Joshi, Aparna, and Hyuntak Roh. 2009. "The Role of Context in Work Team Diversity Research: A Meta-Analytic Review." Academy of Management Journal 52 (3): 599627.

Kelly, Erin, and Frank Dobbin. 1998. "How Affirmative Action Became Diversity Management Employer Response to Antidiscrimination Law, 1961 to 1996." American Behavioral Scientist 41 (7): 960-984.

Klarsfeld, A. (ed). 2010. International Handbook on Diversity Management at Work: Country Perspectives on Diversity and Equal Treatment. Cheltenham and Northampton: Edward Elgar.

Konrad, Alison M., Yang Yang, and Cara C. Maurer. 2016. "Antecedents and Outcomes of Diversity and Equality Management Systems: An Integrated Institutional Agency and Strategic Human Resource Management Approach." Human Resource Management 55 (1): 83-107.

Lamkin Broome, Lissa, and Kimberly D. Krawiec. 2008. "Signaling through Board Diversity: Is Anyone Listening." University of Cincinnati Law Review 77: 431-464.

Lee, Matthew, and Laura Huang. 2018. "Gender Bias, Social Impact Framing, and Evaluation of Entrepreneurial Ventures." Organization Science 29 (1): 1-16.

Lee, Peggy M., and Erika Hayes James. 2007. "She'-e-Os: Gender Effects and Investor Reactions to the Announcements of Top Executive Appointments." Strategic Management Journal 28 (3): 227-241.

Lucas, Jeffrey W. 2003. "Status Processes and the Institutionalization of Women as Leaders." American Sociological Review 68 (3): 464-480.

Matsa, David A., and Amalia R. Miller. 2013. "A Female Style in Corporate Leadership? Evidence from Quotas." American Economic Journal: Applied Economics 5 (3): 136169. 
McMahon, Anne M. 2010. “Does Workplace Diversity Matter? A Survey of Empirical Studies on Diversity and Firm Performance, 2000-09." Journal of Diversity Management 5 (2): 37-48.

Meyer, John W., and Brian Rowan. 1977. "Institutionalized Organizations: Formal Structure as Myth and Ceremony." American Journal of Sociology 83(2): 340-363.

Nishii, Lisa H., and Mustafa F. Özbilgin. 2007. "Global Diversity Management: Towards a Conceptual Framework." International Journal of Human Resource Management 18 (11): 1883-1894.

Post, Corinne, and Kris Byron. 2015. "Women on Boards and Firm Financial Performance: A Meta-Analysis." Academy of Management Journal 58 (5): 1546-1571.

Powell, Walter W., and Paul J. DiMaggio (eds.). 2012. The New Institutionalism in Organizational Analysis. Chicago: University of Chicago Press.

Richard, Orlando. 2000. "Racial Diversity, Business Strategy, and Firm Performance: A Resource-Based View.” Academy of Management Journal 43 (2): 164-177.

Richard, Orlando, Tim Barnett, Sean Dwyer, and Ken Chadwick. 2004. "Cultural Diversity in Management, Firm Performance, and the Moderating Role of Entrepreneurial Orientation Dimensions." Academy of Management Journal 47 (2): 255-266.

Richard, Orlando, David Ford, and Kiran Ismail. 2006. "Exploring the Performance Effects of Visible Attribute Diversity: The Moderating Role of Span of Control and Organizational Life Cycle." International Journal of Human Resource Management 17 (12): 2091-2109.

Roberson, Quinetta M., and Hyeon Jeong Park. 2007. "Examining the Link between Diversity and Firm Performance: The Effects of Diversity Reputation and Leader Racial Diversity." Group \& Organization Management 32 (5): 548-568.

Scott, W. Richard. 1987. "The Adolescence of Institutional Theory." Administrative Science Quarterly 32(4): 493-511.

___. 1991. "Unpacking Institutional Arguments." In W. B. Powell and P. J. DiMaggio (eds.), The New Institutionalism in Organizational Analysis, 164-182. Chicago, London: University of Chicago Press.

-_- 1995. Institutions and Organizations: Foundations for Organizational Science. London: Sage.

Scott, W. Richard, and John W. Meyer. 1982. The Organization of Institutional Sectors. Washington, D.C.: ERIC Clearinghouse.

Shore, Lynn M., Beth G. Chung-Herrera, Michelle A. Dean, Karen Holcombe Ehrhart, Don I. Jung, Amy E. Randel, and Gangaram Singh. 2009. "Diversity in Organizations: Where Are We Now and Where Are We Going?" Human Resource Management Review 19 (2): 117-133.

Skaggs, Sheryl, Kevin Stainback, and Phyllis Duncan. 2012. "Shaking Things Up or Business as Usual? The Influence of Female Corporate Executives and Board of Directors on Women's Managerial Representation." Social Science Research 41 (4): 936-948.

Smith, Edward Bishop, and Kevin Gaughan. 2016. "Better in the Shadows? Attention, Media Coverage, and Market Reactions to Female CEO Announcements." Academy of Management Annual Meeting Proceedings 2016 (1): 1069-1074.

Suchman, Mark C. 1995. "Managing Legitimacy: Strategic and Institutional Approaches." Academy of Management Review 20 (3): 571-610. 
Tajfel, Henri. 1981. Human Groups and Social Categories: Studies in Social Psychology. Cambridge: Cambridge University Press.

Thomas, David A., and Robin J. Ely. 1996. "Making Differences Matter." Harvard Business Review 74 (5): 79-90.

Thornton, Patricia H., and William Ocasio. 2008. "Institutional Logics." In Royston Greenwood, Christine Oliver, Roy Suddaby, Kerstin Sahlin (eds.), The Sage Handbook of Organizational Institutionalism, 99-128. London: Sage.

Tsui, Anne S., Terri D. Egan, and Charles A. O’Reilly III. 1992. "Being Different: Relational Demography and Organizational Attachment." Administrative Science Quarterly 37 (4): 549-579.

Turner, John C., Michael A. Hogg, Penelope J. Oakes, Stephen D. Reicher, and Margaret S. Wetherell. 1987. Rediscovering the Social Group: A Self-Categorization Theory. Cambridge, MA: Basil Blackwell.

Van Knippenberg, Daan, S. Alexander Haslam, and Michael J. Platow. 2007. "Unity through Diversity: Value-in-Diversity Beliefs, Work Group Diversity, and Group Identification." Group Dynamics: Theory, Research, and Practice 11 (3): 207-222.

Van Knippenberg, Daan, and Michaela C. Schippers. 2007. "Work Group Diversity." Annual Review of Psychology 58: 515-541.

Van Knippenberg, Daan, Wendy P. van Ginkel, and Astrid C. Homan. 2013. "Diversity Mindsets and the Performance of Diverse Teams." Organizational Behavior and Human Decision Processes 121 (2): 183-193.

Welbourne, Theresa M., Cynthia S. Cycyota, and Claudia J. Ferrante. 2007. "Wall Street Reaction to Women in IPOs: An Examination of Gender Diversity in Top Management Teams." Group \& Organization Management 32 (5): 524-547.

Westphal, James D., and Edward J. Zajac. 1998. "The Symbolic Management of Stockholders: Corporate Governance Reforms and Shareholder Reactions." Administrative Science Quarterly 43 (1): 127-153.

Wharton, Amy S., and James N. Baron. 1987. "So Happy Together? The Impact of Gender Segregation on Men at Work." American Sociological Review 52 (5): 574-587.

Williams, K. Y., and C. A. O’Reilly III. 1998. "Demography and Diversity in Organisations: A Review of 40 Years of Research." In B. M. Staw and L. L. Cummings (eds.), Research in Organizational Behavior Vol. 20." Greenwich, CT: JAI.

Wooten, Melissa, and Andrew John Hoffman. 2016. "Organizational Fields Past, Present and Future." Ross School of Business Paper, No. 1311.

Wright, Erik Olin, Janeen Baxter, and Gunn Elisabeth Birkelund. 1995. "The Gender Gap in Workplace Authority: A Cross-National Study." American Sociological Review 60 (3): 407-435.

Wright, Peter, Stephen P. Ferris, Janine S. Hiller, and Mark Kroll. 1995. "Competitiveness through Management of Diversity: Effects on Stock Price Valuation." Academy of Management Journal 38 (1): 272-287.

Yan, Shipeng, Fabrizio Ferraro, and Juan Almandoz. 2018. "The Rise of Socially Responsible Investment Funds: The Paradoxical Role of the Financial Logic." Administrative Science Quarterly, ePub ahead of print April 12, 2018.

Yang, Yang, and Alison M. Konrad. 2011. "Understanding Diversity Management Practices: Implications of Institutional Theory and Resource-Based Theory." Group \& Organization Management 36 (1): 6-38. 
Zajac, Edward J., and James D. Westphal. 2004. "The Social Construction of Market Value: Institutionalization and Learning Perspectives on Stock Market Reactions." American Sociological Review 69 (3): 433-457.

Zhang, Letian. 2017. "A Fair Game? Racial Bias and Repeated Interaction between NBA Coaches and Players." Administrative Science Quarterly 62 (4): 603-625.

——_. 2018. "Who Loses When a Team Wins? Better Performance Increases Racial Bias." Organization Science forthcoming.

Zimmerman, Monica A., and Gerald J. Zeitz. 2002. "Beyond Survival: Achieving New Venture Growth by Building Legitimacy." Academy of Management Review 27 (3): 414-431.

Zucker, Lynne G. 1987. "Institutional Theories of Organization." Annual Review of Sociology 13: 443-464.

Zuckerman, Ezra W. 1999. "The Categorical Imperative: Securities Analysts and the Illegitimacy Discount." American Journal of Sociology 104 (5): 1398-1438. 


\section{TABLES AND FIGURES}

Table 1a: Firm Distribution by Country

\begin{tabular}{|c|c|c|c|c|c|c|}
\hline Country & $\begin{array}{l}\text { Num firms in } \\
\text { main sample }\end{array}$ & $\begin{array}{l}\text { Num firms } \\
\text { with valid data }\end{array}$ & $\begin{array}{l}\text { Average pct of } \\
\text { women workers } \\
\text { in sample }\end{array}$ & $\begin{array}{l}\text { Pct women } \\
\text { among all } \\
\text { board members }\end{array}$ & $\begin{array}{l}\text { Pct firms } \\
\text { with diversity } \\
\text { policies }\end{array}$ & $\begin{array}{l}\text { Laws supporting } \\
\text { women at work } \\
\text { (score) }\end{array}$ \\
\hline Australia & 187 & 142 & 36 & 11 & 77 & 6.5 \\
\hline Austria & 20 & 15 & 27 & 9 & 77 & 10 \\
\hline Belgium & 10 & 10 & 41 & 11 & 68 & 9.3 \\
\hline Brazil & 66 & 58 & 28 & 5 & 72 & 7 \\
\hline Canada & 57 & 47 & 31 & 11 & 42 & 8 \\
\hline Chile & 5 & 5 & 26 & 3 & 58 & 6 \\
\hline China & 16 & 14 & 43 & 8 & 38 & 6 \\
\hline Colombia & 20 & 18 & 36 & 9 & 59 & 5 \\
\hline Denmark & 10 & 10 & 44 & 16 & 63 & 8 \\
\hline Finland & 9 & 9 & 32 & 23 & 75 & 10 \\
\hline France & 48 & 47 & 38 & 15 & 86 & 8 \\
\hline Germany & 39 & 39 & 30 & 13 & 72 & 10 \\
\hline Hong Kong & 36 & 21 & 43 & 9 & 36 & 7 \\
\hline India & 30 & 22 & 14 & 4 & 36 & 5 \\
\hline Indonesia & 44 & 12 & 15 & 5 & 75 & 5 \\
\hline Ireland & 14 & 7 & 31 & 9 & 57 & 7 \\
\hline Israel & 19 & 6 & 45 & 17 & 64 & 7 \\
\hline Italy & 18 & 18 & 31 & 8 & 68 & 8 \\
\hline Japan & 150 & 44 & 27 & 1 & 43 & 10 \\
\hline Malaysia & 17 & 13 & 37 & 8 & 59 & 4 \\
\hline Mexico & 10 & 9 & 23 & 6 & 67 & 6 \\
\hline Netherlands & 17 & 15 & 37 & 13 & 76 & 9 \\
\hline Norway & 6 & 6 & 30 & 37 & 86 & 8 \\
\hline Philippines & 30 & 7 & 40 & 11 & 57 & 5 \\
\hline Russia & 14 & 10 & 44 & 11 & 33 & 8 \\
\hline Singapore & 26 & 13 & 39 & 6 & 36 & 5 \\
\hline South Africa & 30 & 30 & 41 & 16 & 83 & 6 \\
\hline South Korea & 21 & 21 & 25 & 1 & 61 & 8 \\
\hline Spain & 20 & 20 & 37 & 10 & 84 & 9 \\
\hline Sweden & 26 & 26 & 36 & 27 & 84 & 8 \\
\hline Switzerland & 33 & 32 & 39 & 9 & 65 & 6.6 \\
\hline Taiwan & 12 & 12 & 37 & 5 & 67 & 8 \\
\hline Thailand & 50 & 16 & 35 & 8 & 63 & 4 \\
\hline United Kingdom & 105 & 103 & 40 & 12 & 90 & 7 \\
\hline United States & 488 & 192 & 35 & 12 & 51 & 6 \\
\hline Total & 1703 & 1069 & 35 & 10 & 67 & 7.3 \\
\hline
\end{tabular}


Table 1b: Firm Distribution by Industry

\begin{tabular}{|c|c|c|c|c|c|}
\hline & $\begin{array}{l}\text { Num firms in } \\
\text { main sample }\end{array}$ & $\begin{array}{l}\text { Num firms } \\
\text { with valid } \\
\text { data }\end{array}$ & $\begin{array}{l}\text { Average pct of } \\
\text { women workers } \\
\text { in sample }\end{array}$ & $\begin{array}{l}\text { Pct women } \\
\text { among all board } \\
\text { members }\end{array}$ & $\begin{array}{l}\text { Pet firms } \\
\text { with diversity } \\
\text { policies }\end{array}$ \\
\hline \multicolumn{6}{|l|}{ GICS industry group } \\
\hline Automobiles \& Components & 42 & 24 & 14 & 6 & 66 \\
\hline Banks & 130 & 89 & 55 & 12 & 59 \\
\hline Capital Goods & 159 & 87 & 21 & 9 & 46 \\
\hline Commercial \& Professional Services & 46 & 34 & 34 & 12 & 77 \\
\hline Consumer Durables \& Apparel & 52 & 34 & 44 & 12 & 67 \\
\hline Consumer Services & 46 & 26 & 47 & 12 & 69 \\
\hline Diversified Financials & 68 & 37 & 42 & 11 & 64 \\
\hline Energy & 117 & 79 & 24 & 8 & 59 \\
\hline Food \& Staples Retailing & 28 & 20 & 51 & 14 & 62 \\
\hline Food, Beverage \& Tobacco & 82 & 46 & 31 & 11 & 75 \\
\hline Health Care Equipment \& Services & 53 & 23 & 54 & 13 & 72 \\
\hline Household \& Personal Products & 20 & 14 & 43 & 17 & 67 \\
\hline Insurance & 52 & 31 & 54 & 13 & 72 \\
\hline Materials & 194 & 151 & 17 & 8 & 67 \\
\hline Media & 51 & 32 & 48 & 14 & 64 \\
\hline Pharmaceuticals \& Biotechnology & 56 & 30 & 46 & 10 & 66 \\
\hline Real Estate & 102 & 50 & 48 & 10 & 61 \\
\hline Retailing & 64 & 31 & 56 & 15 & 53 \\
\hline Semiconductors & 25 & 10 & 32 & 7 & 72 \\
\hline Software \& Services & 51 & 26 & 30 & 10 & 69 \\
\hline Technology Hardware & 44 & 22 & 33 & 9 & 75 \\
\hline Telecommunication Services & 52 & 38 & 39 & 11 & 90 \\
\hline Transportation & 63 & 46 & 32 & 10 & 73 \\
\hline Utilities & 106 & 89 & 23 & 12 & 48 \\
\hline Total & 1703 & 1069 & 35 & 9 & 57 \\
\hline
\end{tabular}


Table 2a: Variable Summary

\begin{tabular}{llllll}
\hline Variables & Mean & SD & Min & Max \\
\hline 1 & Gender Diversity (t-1) & 0.39 & 0.1 & 0 & 0.5 \\
2 & Country Avg Female Pct on Boards & 0.11 & 0.1 & 0.01 & 0.38 \\
3 & Industry Avg Female Pct on Boards & 0.09 & 0.02 & 0.03 & 0.15 \\
4 & Country Pct Firms with Diversity Policy & 0.67 & 0.2 & 0.07 & 0.96 \\
5 & Industry Pct Firms with Diversity Policy & 0.57 & 0.1 & 0.22 & 0.90 \\
6 & Country Laws Supporting Women at Work & 7.3 & 1.5 & 4 & 10 \\
7 & Debt-to-Equity Ratio (log) & 4.0 & 1.4 & 0 & 11.8 \\
8 & Total Employees (log) & 9.9 & 2.0 & 1.4 & 21.7 \\
9 & Employee Turnover (pct) & 0.03 & 0.3 & -5 & 1 \\
10 & Firm Diversity Policy & 0.87 & 0.3 & 0 & 1 \\
11 & Pct Females on Boards & 0.15 & 0.1 & 0.7 \\
12 & Return on Assets & 5.2 & 8.1 & -84 & 115 \\
13 & Tobin's Q (log) & 0.28 & 0.6 & -3.5 & 3.6 \\
\hline
\end{tabular}

\section{Table 2b: Correlations}

\begin{tabular}{|c|c|c|c|c|c|c|c|c|c|c|c|c|c|c|}
\hline \multicolumn{2}{|c|}{ Variables } & $\mathbf{1}$ & 2 & 3 & 4 & 5 & 6 & 7 & 8 & 9 & 10 & 11 & 12 & 13 \\
\hline 1 & Gender Diversity (t-1) & 1 & & & & & & & & & & & & \\
\hline 2 & $\begin{array}{l}\text { Country Avg Female Pct } \\
\text { on Boards }\end{array}$ & 0.1 & 1 & & & & & & & & & & & \\
\hline 3 & $\begin{array}{l}\text { Industry Avg Female Pct } \\
\text { on Boards }\end{array}$ & 0.4 & 0.1 & 1 & & & & & & & & & & \\
\hline 4 & $\begin{array}{l}\text { Country Pct Firms with } \\
\text { Diversity Policy }\end{array}$ & 0.1 & 0.5 & 0.2 & 1 & & & & & & & & & \\
\hline 5 & $\begin{array}{l}\text { Industry Pct Firms with } \\
\text { Diversity Policy }\end{array}$ & 0.0 & 0.2 & 0.4 & 0.4 & 1 & & & & & & & & \\
\hline 6 & $\begin{array}{l}\text { Country Laws Supporting } \\
\text { Women at Work }\end{array}$ & -0.0 & 0.1 & -0.1 & 0.2 & -0.1 & 1 & & & & & & & \\
\hline 7 & $\begin{array}{l}\text { Debt-to-Equity Ratio } \\
(\log )\end{array}$ & 0.1 & 0.0 & 0.1 & 0.0 & 0.0 & 0.0 & 1 & & & & & & \\
\hline 8 & Total Employees (log) & 0.0 & -0.0 & -0.0 & 0.0 & 0.1 & 0.0 & 0.1 & 1 & & & & & \\
\hline 9 & Employee Turnover (pct) & -0.0 & -0.0 & -0.0 & 0.0 & 0.0 & -0.1 & -0.1 & 0.2 & 1 & & & & \\
\hline 10 & Firm Diversity Policy & 0.1 & 0.2 & 0.0 & 0.2 & 0.1 & 0.0 & 0.0 & 0.2 & -0.0 & 1 & & & \\
\hline 11 & Pct Females on Boards & 0.2 & 0.6 & 2.2 & 0.2 & 0.1 & -0.0 & 0.1 & 0.1 & -0.1 & 0.1 & 1 & & \\
\hline 12 & Return on Assets & -0.0 & 0.0 & -0.0 & -0.0 & 0.0 & -0.2 & -0.3 & -0.0 & 0.1 & 0.0 & 0.0 & 1 & \\
\hline 13 & Tobin's Q (log) & 0.1 & 0.1 & 0.00 & -0.0 & 0.1 & -0.2 & -0.3 & -0.0 & 0.00 & 0.0 & 0.1 & 0.5 & 1 \\
\hline
\end{tabular}


Table 3 Predicting Firm Performance, 2007-2014

\begin{tabular}{|c|c|c|c|c|c|c|c|c|c|c|}
\hline \multirow[b]{2}{*}{ Variable } & \multicolumn{5}{|c|}{ ROA } & \multicolumn{5}{|c|}{ Tobin's Q } \\
\hline & (1) & (2) & (3) & (4) & (5) & (6) & (7) & (8) & (9) & (10) \\
\hline Gender Diversity (t-1) & $\begin{array}{l}-9.56 \\
(5.76)\end{array}$ & $\begin{array}{c}-103.36 * * \\
(23.68)\end{array}$ & $\begin{array}{c}-35.69 * * \\
(8.38)\end{array}$ & $\begin{array}{l}-99.67 * * \\
(24.35)\end{array}$ & $\begin{array}{c}-27.82 * * \\
(7.27)\end{array}$ & $\begin{array}{l}-0.20 \\
(0.25)\end{array}$ & $\begin{array}{c}-3.37 * * \\
(1.00)\end{array}$ & $\begin{array}{c}-1.28 * * \\
(0.47)\end{array}$ & $\begin{array}{c}-3.29 * * \\
(1.02)\end{array}$ & $\begin{array}{l}-0.87 * \\
(0.38)\end{array}$ \\
\hline $\begin{array}{l}\text { Gender Diversity (t-1) x Country Avg } \\
\text { Female Pct on Board }\end{array}$ & & $\begin{array}{l}75.74 * \\
(32.34)\end{array}$ & & & & & $\begin{array}{l}3.75 * \\
(1.48)\end{array}$ & & & \\
\hline $\begin{array}{l}\text { Gender Diversity (t-1) x Industry Avg } \\
\text { Female Pct on Board }\end{array}$ & & & $\begin{array}{c}362.21^{* *} \\
(86.78)\end{array}$ & & & & & $\begin{array}{c}14.95 * * \\
(5.39)\end{array}$ & & \\
\hline $\begin{array}{l}\text { Gender Diversity (t-1) x Country Pct } \\
\text { Firms with Diversity Policy }\end{array}$ & & & & $\begin{array}{l}17.38 * \\
(8.41)\end{array}$ & & & & & $\begin{array}{l}1.21 * * \\
(0.41)\end{array}$ & \\
\hline $\begin{array}{l}\text { Gender Diversity (t-1) x Industry Pct } \\
\text { Firms with Diversity Policy }\end{array}$ & & & & & $\begin{array}{c}38.24 * * \\
(9.17)\end{array}$ & & & & & $\begin{array}{l}1.38 * \\
(0.54)\end{array}$ \\
\hline $\begin{array}{l}\text { Gender Diversity (t-1) x Country Laws } \\
\text { Supporting Women at Work }\end{array}$ & & $\begin{array}{c}12.04 * * \\
(2.88)\end{array}$ & & $\begin{array}{c}11.01 * * \\
(2.83)\end{array}$ & & & $\begin{array}{c}0.39 * * \\
(0.12)\end{array}$ & & $\begin{array}{l}0.32 * * \\
(0.12)\end{array}$ & \\
\hline Debt to Equity Ratio (log) & $\begin{array}{c}-2.38 * * \\
(0.29)\end{array}$ & $\begin{array}{c}-2.36^{* *} \\
(0.29)\end{array}$ & $\begin{array}{l}-2.32 * * \\
(0.29)\end{array}$ & $\begin{array}{c}-2.34 * * \\
(0.29)\end{array}$ & $\begin{array}{l}-2.29 * * \\
(0.29)\end{array}$ & $\begin{array}{c}-0.04 * * \\
(0.01)\end{array}$ & $\begin{array}{c}-0.04 * * \\
(0.01)\end{array}$ & $\begin{array}{c}-0.04 * * \\
(0.01)\end{array}$ & $\begin{array}{c}-0.04 * * \\
(0.01)\end{array}$ & $\begin{array}{c}-0.04 * * \\
(0.01)\end{array}$ \\
\hline Total Employees (log) & $\begin{array}{l}-0.37 \\
(0.20)\end{array}$ & $\begin{array}{l}-0.34 \\
(0.19)\end{array}$ & $\begin{array}{l}-0.37 \\
(0.20)\end{array}$ & $\begin{array}{l}-0.33 \\
(0.19)\end{array}$ & $\begin{array}{l}-0.36 \\
(0.20)\end{array}$ & $\begin{array}{l}-0.01 \\
(0.01)\end{array}$ & $\begin{array}{l}-0.01 \\
(0.01)\end{array}$ & $\begin{array}{l}-0.01 \\
(0.01)\end{array}$ & $\begin{array}{l}-0.01 \\
(0.01)\end{array}$ & $\begin{array}{l}-0.01 \\
(0.01)\end{array}$ \\
\hline Employee Turnover (in pct) & $\begin{array}{l}1.12 * \\
(0.51)\end{array}$ & $\begin{array}{l}1.13^{*} \\
(0.51)\end{array}$ & $\begin{array}{l}1.13^{*} \\
(0.51)\end{array}$ & $\begin{array}{l}1.12 * \\
(0.51)\end{array}$ & $\begin{array}{l}1.11^{*} \\
(0.52)\end{array}$ & $\begin{array}{l}0.03 * \\
(0.01)\end{array}$ & $\begin{array}{l}0.03 * \\
(0.01)\end{array}$ & $\begin{array}{l}0.03^{*} \\
(0.01)\end{array}$ & $\begin{array}{l}0.03 * \\
(0.01)\end{array}$ & $\begin{array}{l}0.03 * \\
(0.01)\end{array}$ \\
\hline Firm Diversity Policy & $\begin{array}{l}-0.59 \\
(0.50)\end{array}$ & $\begin{array}{l}-0.55 \\
(0.50)\end{array}$ & $\begin{array}{l}-0.44 \\
(0.50)\end{array}$ & $\begin{array}{l}-0.44 \\
(0.50)\end{array}$ & $\begin{array}{l}-0.33 \\
(0.50)\end{array}$ & $\begin{array}{c}0.03 \\
(0.02)\end{array}$ & $\begin{array}{c}0.03 \\
(0.02)\end{array}$ & $\begin{array}{c}0.04 \\
(0.02)\end{array}$ & $\begin{array}{c}0.04 \\
(0.02)\end{array}$ & $\begin{array}{c}0.04 \\
(0.02)\end{array}$ \\
\hline Female Pct on Boards & $\begin{array}{c}0.11 \\
(2.44)\end{array}$ & $\begin{array}{c}0.03 \\
(2.43)\end{array}$ & $\begin{array}{c}0.18 \\
(2.42)\end{array}$ & $\begin{array}{c}0.05 \\
(2.42)\end{array}$ & $\begin{array}{c}0.14 \\
(2.41)\end{array}$ & $\begin{array}{l}-0.15 \\
(0.08)\end{array}$ & $\begin{array}{l}-0.15 \\
(0.08)\end{array}$ & $\begin{array}{l}-0.15 \\
(0.08)\end{array}$ & $\begin{array}{l}-0.15 \\
(0.08)\end{array}$ & $\begin{array}{l}-0.15 \\
(0.08)\end{array}$ \\
\hline Industry Avg Female Pct on Board & $\begin{array}{c}17.67 \\
(21.86)\end{array}$ & $\begin{array}{c}28.84 \\
(21.77)\end{array}$ & $\begin{array}{c}-115.24 * * \\
(39.70)\end{array}$ & & & $\begin{array}{l}-0.44 \\
(1.08)\end{array}$ & $\begin{array}{c}0.05 \\
(1.07)\end{array}$ & $\begin{array}{l}-5.92 * \\
(2.45)\end{array}$ & & \\
\hline Industry Pct Firms with Diversity Policy & & & & $\begin{array}{l}-4.45 \\
(2.84)\end{array}$ & $\begin{array}{c}-20.63^{* *} \\
(4.69)\end{array}$ & & & & $\begin{array}{c}-0.34 * * \\
(0.13)\end{array}$ & $\begin{array}{c}-0.93 * * \\
(0.29)\end{array}$ \\
\hline Return on Assets & & & & & & $\begin{array}{c}0.00 \\
(0.00)\end{array}$ & $\begin{array}{c}0.00 \\
(0.00)\end{array}$ & $\begin{array}{c}0.00 \\
(0.00)\end{array}$ & $\begin{array}{c}0.00 \\
(0.00)\end{array}$ & $\begin{array}{c}0.00 \\
(0.00)\end{array}$ \\
\hline Constant & $\begin{array}{c}-9.75 \\
(21.84)\end{array}$ & $\begin{array}{c}32.59 \\
(24.14)\end{array}$ & $\begin{array}{c}21.50^{*} \\
(8.75)\end{array}$ & $\begin{array}{c}54.34 * * \\
(14.22)\end{array}$ & $\begin{array}{c}22.64 * \\
(9.44)\end{array}$ & $\begin{array}{c}-2.67 * * \\
(0.84)\end{array}$ & $\begin{array}{l}-1.23 \\
(0.95)\end{array}$ & $\begin{array}{l}-0.38 \\
(0.36)\end{array}$ & $\begin{array}{l}1.70 * * \\
(0.57)\end{array}$ & $\begin{array}{c}0.65 \\
(0.39)\end{array}$ \\
\hline Observations & 5,006 & 5,006 & 5,006 & 5,006 & 5,006 & 5,006 & 5,006 & 5,006 & 5,006 & 5,006 \\
\hline R-squared & 0.14 & 0.15 & 0.15 & 0.15 & 0.15 & 0.42 & 0.42 & 0.42 & 0.43 & 0.42 \\
\hline Number of firms & 1,069 & 1,069 & 1,069 & 1,069 & 1,069 & 1,069 & 1,069 & 1,069 & 1,069 & 1,069 \\
\hline Firm fixed effects & Yes & Yes & Yes & Yes & Yes & Yes & Yes & Yes & Yes & Yes \\
\hline Country-year fixed effects & Yes & Yes & Yes & Yes & Yes & Yes & Yes & Yes & Yes & Yes \\
\hline
\end{tabular}


Table 4 Predicting Firm Performance, Additional Controls

\begin{tabular}{|c|c|c|c|c|c|c|c|c|c|c|}
\hline \multirow[b]{2}{*}{ Variable } & \multicolumn{5}{|c|}{ ROA } & \multicolumn{5}{|c|}{ Tobin's Q } \\
\hline & (1) & (2) & (3) & (4) & (5) & (6) & (7) & (8) & (9) & (10) \\
\hline Gender Diversity (t-1) & $\begin{array}{l}-63.93 \\
(88.79)\end{array}$ & $\begin{array}{l}-93.04 \\
(88.46)\end{array}$ & $\begin{array}{l}-27.54 \\
(87.66)\end{array}$ & $\begin{array}{l}-94.32 \\
(89.01)\end{array}$ & $\begin{array}{l}-24.53 \\
(88.17)\end{array}$ & $\begin{array}{l}-5.53 \\
(4.10)\end{array}$ & $\begin{array}{l}-6.29 \\
(4.16)\end{array}$ & $\begin{array}{l}-4.14 \\
(3.95)\end{array}$ & $\begin{array}{l}-6.21 \\
(4.08)\end{array}$ & $\begin{array}{l}-4.07 \\
(3.98)\end{array}$ \\
\hline $\begin{array}{l}\text { Gender Diversity (t-1) x Country Avg } \\
\text { Female Pct on Board }\end{array}$ & & $\begin{array}{l}81.32 * \\
(32.16)\end{array}$ & & & & & $\begin{array}{l}3.78 * \\
(1.57)\end{array}$ & & & \\
\hline $\begin{array}{l}\text { Gender Diversity (t-1) x Industry Avg } \\
\text { Female Pct on Board }\end{array}$ & & & $\begin{array}{c}365.59 * * \\
(91.59)\end{array}$ & & & & & $\begin{array}{c}14.14 * \\
(5.84)\end{array}$ & & \\
\hline $\begin{array}{l}\text { Gender Diversity (t-1) x Country Pct } \\
\text { Firms with Diversity Policy }\end{array}$ & & & & $\begin{array}{l}19.87 * \\
(8.46)\end{array}$ & & & & & $\begin{array}{l}1.30 * * \\
(0.43)\end{array}$ & \\
\hline $\begin{array}{l}\text { Gender Diversity (t-1) x Industry Pct } \\
\text { Firms with Diversity Policy }\end{array}$ & & & & & $\begin{array}{c}40.49 * * \\
(8.78)\end{array}$ & & & & & $\begin{array}{l}1.45^{* *} \\
(0.54)\end{array}$ \\
\hline $\begin{array}{l}\text { Gender Diversity (t-1) x Country Laws } \\
\text { Supporting Women at Work }\end{array}$ & & $\begin{array}{c}12.80 * * \\
(3.09)\end{array}$ & & $\begin{array}{c}11.46^{* *} \\
(3.10)\end{array}$ & & & $\begin{array}{c}0.43 * * \\
(0.13)\end{array}$ & & $\begin{array}{c}0.34 * * \\
(0.13)\end{array}$ & \\
\hline $\begin{array}{l}\text { Gender Diversity }(\mathrm{t}-1) \text { x Gender Wage } \\
\text { Gap }\end{array}$ & $\begin{array}{l}-0.17 \\
(0.57)\end{array}$ & $\begin{array}{l}-0.06 \\
(0.54)\end{array}$ & $\begin{array}{c}0.19 \\
(0.56)\end{array}$ & $(0.56)$ & $(0.56)$ & $\begin{array}{c}0.03 \\
(0.02)\end{array}$ & $\begin{array}{c}0.03 \\
(0.02)\end{array}$ & $\begin{array}{c}0.04 \\
(0.02)\end{array}$ & $(0.02)$ & $\begin{array}{c}0.04 \\
(0.02)\end{array}$ \\
\hline $\begin{array}{l}\text { Gender Diversity }(\mathrm{t}-1) \times \text { Female to Male } \\
\text { Years of Schooling }\end{array}$ & $\begin{array}{l}-41.16 \\
(61.93)\end{array}$ & $\begin{array}{l}-27.38 \\
(64.25)\end{array}$ & $\begin{array}{l}-81.48 \\
(58.02)\end{array}$ & $\begin{array}{l}-32.95 \\
(61.50)\end{array}$ & $\begin{array}{l}-95.31 \\
(56.81)\end{array}$ & $\begin{array}{l}0.87 \\
(3.76)\end{array}$ & $\begin{array}{c}0.92 \\
(3.98)\end{array}$ & $\begin{array}{l}-0.70 \\
(3.43)\end{array}$ & $\begin{array}{l}0.12 \\
(3.59)\end{array}$ & $\begin{array}{l}-1.11 \\
(3.44)\end{array}$ \\
\hline $\begin{array}{l}\text { Gender Diversity (t-1) x GDP per Capita } \\
(\log )\end{array}$ & $\begin{array}{l}8.94 \\
(5.68)\end{array}$ & $\begin{array}{c}0.23 \\
(6.64)\end{array}$ & $\begin{array}{c}6.76 \\
(5.57)\end{array}$ & $\begin{array}{c}1.11 \\
(6.79)\end{array}$ & $\begin{array}{c}7.77 \\
(5.66)\end{array}$ & $\begin{array}{l}0.35 \\
(0.35)\end{array}$ & $\begin{array}{c}0.06 \\
(0.38)\end{array}$ & $\begin{array}{c}0.26 \\
(0.34)\end{array}$ & $\begin{array}{c}0.13 \\
(0.38)\end{array}$ & $\begin{array}{c}0.30 \\
(0.34)\end{array}$ \\
\hline Gender Diversity (t-1) x Service Industry & $\begin{array}{c}22.57 \\
(12.31)\end{array}$ & $\begin{array}{l}28.43 * \\
(12.92)\end{array}$ & $\begin{array}{c}10.26 \\
(13.09)\end{array}$ & $\begin{array}{l}28.28 * \\
(13.14)\end{array}$ & $\begin{array}{c}21.28 \\
(12.66)\end{array}$ & $\begin{array}{c}0.73 \\
(0.46)\end{array}$ & $\begin{array}{l}0.94 * \\
(0.48)\end{array}$ & $\begin{array}{c}0.26 \\
(0.49)\end{array}$ & $\begin{array}{c}0.94 \\
(0.48)\end{array}$ & $\begin{array}{c}0.68 \\
(0.47)\end{array}$ \\
\hline $\begin{array}{l}\text { Gender Diversity (t-1) x Technology } \\
\text { Industry }\end{array}$ & $\begin{array}{c}-191.37 \\
(99.96)\end{array}$ & $\begin{array}{c}-186.26 * \\
(92.54)\end{array}$ & $\begin{array}{c}-203.04 * \\
(98.84)\end{array}$ & $\begin{array}{c}-188.21^{*} \\
(93.24)\end{array}$ & $\begin{array}{c}-194.64 * \\
(98.00)\end{array}$ & $\begin{array}{l}8.81 * * \\
(3.06)\end{array}$ & $\begin{array}{l}8.89 * * \\
(3.27)\end{array}$ & $\begin{array}{c}8.32 * * \\
(3.09)\end{array}$ & $\begin{array}{l}8.65 * * \\
(3.19)\end{array}$ & $\begin{array}{l}8.61 * * \\
(3.08)\end{array}$ \\
\hline $\begin{array}{l}\text { Gender Diversity (t-1) x Industry Gender } \\
\text { Segregation }\end{array}$ & $\begin{array}{l}-1.90 \\
(1.74)\end{array}$ & $\begin{array}{l}-1.62 \\
(1.66)\end{array}$ & $\begin{array}{l}-1.83 \\
(1.73)\end{array}$ & $\begin{array}{l}-1.79 \\
(1.65)\end{array}$ & $\begin{array}{l}-1.42 \\
(1.72)\end{array}$ & $\begin{array}{c}0.03 \\
(0.10)\end{array}$ & $\begin{array}{c}0.04 \\
(0.10)\end{array}$ & $\begin{array}{c}0.03 \\
(0.10)\end{array}$ & $\begin{array}{c}0.03 \\
(0.09)\end{array}$ & $\begin{array}{c}0.05 \\
(0.10)\end{array}$ \\
\hline Debt to Equity Ratio (log) & $\begin{array}{c}-2.36^{* *} \\
(0.29)\end{array}$ & $\begin{array}{c}-2.34 * * \\
(0.28)\end{array}$ & $\begin{array}{c}-2.31^{* *} \\
(0.28)\end{array}$ & $\begin{array}{c}-2.31 * * \\
(0.29)\end{array}$ & $\begin{array}{c}-2.27 * * \\
(0.28)\end{array}$ & $\begin{array}{c}-0.04 * * \\
(0.01)\end{array}$ & $\begin{array}{c}-0.04 * * \\
(0.01)\end{array}$ & $\begin{array}{c}-0.04 * * \\
(0.01)\end{array}$ & $\begin{array}{c}-0.04 * * \\
(0.01)\end{array}$ & $\begin{array}{c}-0.04 * * \\
(0.01)\end{array}$ \\
\hline Total Employees (log) & $\begin{array}{l}-0.35 \\
(0.20)\end{array}$ & $\begin{array}{l}-0.32 \\
(0.20)\end{array}$ & $\begin{array}{l}-0.37 \\
(0.20)\end{array}$ & $\begin{array}{l}-0.31 \\
(0.20)\end{array}$ & $\begin{array}{l}-0.35 \\
(0.20)\end{array}$ & $\begin{array}{l}-0.01 \\
(0.01)\end{array}$ & $\begin{array}{l}-0.01 \\
(0.01)\end{array}$ & $\begin{array}{l}-0.01 \\
(0.01)\end{array}$ & $\begin{array}{l}-0.01 \\
(0.01)\end{array}$ & $\begin{array}{l}-0.01 \\
(0.01)\end{array}$ \\
\hline Employee Turnover (in pct) & $\begin{array}{l}1.12^{*} \\
(0.52)\end{array}$ & $\begin{array}{l}1.12^{*} \\
(0.52)\end{array}$ & $\begin{array}{l}1.15^{*} \\
(0.52)\end{array}$ & $\begin{array}{l}1.11^{*} \\
(0.52)\end{array}$ & $\begin{array}{l}1.12 * \\
(0.53)\end{array}$ & $\begin{array}{l}0.03 * \\
(0.01)\end{array}$ & $\begin{array}{l}0.03^{*} \\
(0.01)\end{array}$ & $\begin{array}{l}0.03^{*} \\
(0.01)\end{array}$ & $\begin{array}{l}0.03 * \\
(0.01)\end{array}$ & $\begin{array}{l}0.03^{*} \\
(0.01)\end{array}$ \\
\hline Firm Diversity Policy & $\begin{array}{l}-0.64 \\
(0.51)\end{array}$ & $\begin{array}{l}-0.60 \\
(0.50)\end{array}$ & $\begin{array}{l}-0.50 \\
(0.50)\end{array}$ & $\begin{array}{l}-0.48 \\
(0.50)\end{array}$ & $\begin{array}{l}-0.41 \\
(0.50)\end{array}$ & $\begin{array}{c}0.03 \\
(0.02)\end{array}$ & $\begin{array}{c}0.03 \\
(0.02)\end{array}$ & $\begin{array}{c}0.04 \\
(0.02)\end{array}$ & $\begin{array}{c}0.04 \\
(0.02)\end{array}$ & $\begin{array}{c}0.04 \\
(0.02)\end{array}$ \\
\hline Female Pct on Boards & $\begin{array}{c}0.25 \\
(2.47)\end{array}$ & $\begin{array}{c}0.09 \\
(2.47)\end{array}$ & $\begin{array}{c}0.26 \\
(2.46)\end{array}$ & $\begin{array}{c}0.12 \\
(2.46)\end{array}$ & $\begin{array}{c}0.22 \\
(2.45)\end{array}$ & $\begin{array}{l}-0.15 \\
(0.08)\end{array}$ & $\begin{array}{l}-0.15 \\
(0.08)\end{array}$ & $\begin{array}{l}-0.15 \\
(0.08)\end{array}$ & $\begin{array}{l}-0.15 \\
(0.08)\end{array}$ & $\begin{array}{l}-0.15 \\
(0.08)\end{array}$ \\
\hline Industry Avg Female Pct on Board & $\begin{array}{c}20.13 \\
(21.76)\end{array}$ & $\begin{array}{c}30.32 \\
(21.71)\end{array}$ & $\begin{array}{c}-116.65^{* *} \\
(41.50)\end{array}$ & & & $\begin{array}{l}-0.51 \\
(1.06)\end{array}$ & $\begin{array}{l}-0.08 \\
(1.06)\end{array}$ & $\begin{array}{c}-5.79 * \\
(2.64)\end{array}$ & & \\
\hline Industry Pct Firms with Diversity Policy & & & & $\begin{array}{l}-4.19 \\
(2.86)\end{array}$ & $\begin{array}{c}-21.40^{* *} \\
(4.53)\end{array}$ & & & & $\begin{array}{l}-0.33 * \\
(0.13)\end{array}$ & $\begin{array}{c}-0.95^{* *} \\
(0.29)\end{array}$ \\
\hline Return on Assets & & & & & & $\begin{array}{l}0.00^{*} \\
(0.00)\end{array}$ & $\begin{array}{c}0.00 \\
(0.00)\end{array}$ & $\begin{array}{c}0.00 \\
(0.00)\end{array}$ & $\begin{array}{c}0.00 \\
(0.00)\end{array}$ & $\begin{array}{c}0.00 \\
(0.00)\end{array}$ \\
\hline Constant & $\begin{array}{c}-4.35 \\
(26.85)\end{array}$ & $\begin{array}{c}35.42 \\
(28.55)\end{array}$ & $\begin{array}{c}17.91 \\
(10.61)\end{array}$ & $\begin{array}{c}54.85^{* *} \\
(14.78)\end{array}$ & $\begin{array}{l}19.91 * \\
(9.82)\end{array}$ & $\begin{array}{c}-3.36^{* *} \\
(1.11)\end{array}$ & $\begin{array}{l}-2.09 \\
(1.18)\end{array}$ & $\begin{array}{l}-0.97 * \\
(0.45)\end{array}$ & $\begin{array}{l}1.35^{*} \\
(0.58)\end{array}$ & $\begin{array}{c}0.26 \\
(0.41)\end{array}$ \\
\hline Observations & 5,006 & 5,006 & 5,006 & 5,006 & 5,006 & 5,006 & 5,006 & 5,006 & 5,006 & 5,006 \\
\hline R-squared & 0.15 & 0.15 & 0.15 & 0.15 & 0.15 & 0.42 & 0.43 & 0.43 & 0.43 & 0.43 \\
\hline Number of firms & 1,069 & 1,069 & 1,069 & 1,069 & 1,069 & 1,069 & 1,069 & 1,069 & 1,069 & 1,069 \\
\hline Firm fixed effects & Yes & Yes & Yes & Yes & Yes & Yes & Yes & Yes & Yes & Yes \\
\hline Country-year fixed effects & Yes & Yes & Yes & Yes & Yes & Yes & Yes & Yes & Yes & Yes \\
\hline
\end{tabular}


Table 5 Predicting Firm Performance, Including Lagged Dependent Variable

\begin{tabular}{|c|c|c|c|c|c|c|c|c|c|c|}
\hline \multirow[b]{2}{*}{ Variable } & \multicolumn{5}{|c|}{ ROA } & \multicolumn{5}{|c|}{ Tobin's Q } \\
\hline & (1) & (2) & (3) & (4) & (5) & (6) & (7) & (8) & (9) & (10) \\
\hline Gender Diversity (t-1) & $\begin{array}{l}17.96 \\
(9.54)\end{array}$ & $\begin{array}{l}-35.73 \\
(35.19)\end{array}$ & $\begin{array}{l}-30.27 * \\
(13.07)\end{array}$ & $\begin{array}{l}-38.69 \\
(34.08)\end{array}$ & $\begin{array}{l}-30.62 * \\
(12.09)\end{array}$ & $\begin{array}{l}-0.66 \\
(0.49)\end{array}$ & $\begin{array}{l}-1.67 \\
(1.70)\end{array}$ & $\begin{array}{c}-2.10 * * \\
(0.56)\end{array}$ & $\begin{array}{l}-3.01 \\
(1.75)\end{array}$ & $\begin{array}{c}-1.78 * * \\
(0.54)\end{array}$ \\
\hline $\begin{array}{l}\text { Gender Diversity (t-1) x Country Avg } \\
\text { Female Pct on Board }\end{array}$ & & $\begin{array}{l}140.41 \\
(80.07)\end{array}$ & & & & & $\begin{array}{l}-1.82 \\
(2.58)\end{array}$ & & & \\
\hline $\begin{array}{l}\text { Gender Diversity (t-1) x Industry Avg } \\
\text { Female Pct on Board }\end{array}$ & & & $\begin{array}{l}618.06 * * \\
(157.76)\end{array}$ & & & & & $\begin{array}{c}19.39 * * \\
(6.87)\end{array}$ & & \\
\hline $\begin{array}{l}\text { Gender Diversity (t-1) x Country Pct } \\
\text { Firms with Diversity Policy }\end{array}$ & & & & $\begin{array}{l}31.85^{*} \\
(12.39)\end{array}$ & & & & & $\begin{array}{l}1.41^{*} \\
(0.60)\end{array}$ & \\
\hline $\begin{array}{l}\text { Gender Diversity (t-1) x Industry Pct } \\
\text { Firms with Diversity Policy }\end{array}$ & & & & & $\begin{array}{c}80.40 * * \\
(18.66)\end{array}$ & & & & & $\begin{array}{l}1.72 * \\
(0.67)\end{array}$ \\
\hline $\begin{array}{l}\text { Gender Diversity (t-1) x Country } \\
\text { Laws Supporting Women at Work }\end{array}$ & & $\begin{array}{c}5.35 \\
(4.23)\end{array}$ & & $\begin{array}{c}4.76 \\
(4.33)\end{array}$ & & & $\begin{array}{c}0.17 \\
(0.20)\end{array}$ & & $\begin{array}{c}0.18 \\
(0.21)\end{array}$ & \\
\hline Debt to Equity Ratio (log) & $\begin{array}{l}-2.16^{* *} \\
(0.38)\end{array}$ & $\begin{array}{c}-2.12 * * \\
(0.38)\end{array}$ & $\begin{array}{l}-2.08 * * \\
(0.37)\end{array}$ & $\begin{array}{l}-2.00 * * \\
(0.37)\end{array}$ & $\begin{array}{c}-1.96 * * \\
(0.37)\end{array}$ & $\begin{array}{l}-0.02 \\
(0.01)\end{array}$ & $\begin{array}{l}-0.02 \\
(0.01)\end{array}$ & $\begin{array}{l}-0.01 \\
(0.01)\end{array}$ & $\begin{array}{l}-0.02 \\
(0.01)\end{array}$ & $\begin{array}{l}-0.02 \\
(0.01)\end{array}$ \\
\hline Total Employees (log) & $\begin{array}{l}-0.03 \\
(0.15)\end{array}$ & $\begin{array}{l}-0.01 \\
(0.15)\end{array}$ & $\begin{array}{l}-0.01 \\
(0.14)\end{array}$ & $\begin{array}{c}0.08 \\
(0.15)\end{array}$ & $\begin{array}{c}0.04 \\
(0.15)\end{array}$ & $\begin{array}{l}-0.00 \\
(0.01)\end{array}$ & $\begin{array}{l}-0.00 \\
(0.01)\end{array}$ & $\begin{array}{c}0.00 \\
(0.01)\end{array}$ & $\begin{array}{l}-0.00 \\
(0.01)\end{array}$ & $\begin{array}{l}-0.00 \\
(0.01)\end{array}$ \\
\hline Employee Turnover (in pct) & $\begin{array}{l}-0.30 \\
(0.55)\end{array}$ & $\begin{array}{l}-0.29 \\
(0.54)\end{array}$ & $\begin{array}{l}-0.26 \\
(0.55)\end{array}$ & $\begin{array}{l}-0.32 \\
(0.54)\end{array}$ & $\begin{array}{l}-0.24 \\
(0.54)\end{array}$ & $\begin{array}{l}-0.02 \\
(0.03)\end{array}$ & $\begin{array}{l}-0.02 \\
(0.03)\end{array}$ & $\begin{array}{l}-0.02 \\
(0.03)\end{array}$ & $\begin{array}{l}-0.02 \\
(0.03)\end{array}$ & $\begin{array}{l}-0.02 \\
(0.03)\end{array}$ \\
\hline Firm Diversity Policy & $\begin{array}{l}-0.71 \\
(0.74)\end{array}$ & $\begin{array}{l}-0.64 \\
(0.72)\end{array}$ & $\begin{array}{l}-0.41 \\
(0.70)\end{array}$ & $\begin{array}{l}-0.41 \\
(0.72)\end{array}$ & $\begin{array}{l}-0.25 \\
(0.70)\end{array}$ & $\begin{array}{l}-0.02 \\
(0.04)\end{array}$ & $\begin{array}{l}-0.02 \\
(0.04)\end{array}$ & $\begin{array}{l}-0.01 \\
(0.04)\end{array}$ & $\begin{array}{l}-0.01 \\
(0.04)\end{array}$ & $\begin{array}{l}-0.01 \\
(0.04)\end{array}$ \\
\hline Female Pct on Boards & $\begin{array}{c}3.97 \\
(2.90)\end{array}$ & $\begin{array}{c}3.96 \\
(2.88)\end{array}$ & $\begin{array}{c}4.21 \\
(2.95)\end{array}$ & $\begin{array}{c}4.16 \\
(2.77)\end{array}$ & $\begin{array}{c}3.62 \\
(2.74)\end{array}$ & $\begin{array}{l}-0.27 \\
(0.15)\end{array}$ & $\begin{array}{l}-0.27 \\
(0.15)\end{array}$ & $\begin{array}{l}-0.28 \\
(0.15)\end{array}$ & $\begin{array}{l}-0.25 \\
(0.14)\end{array}$ & $\begin{array}{l}-0.25 \\
(0.15)\end{array}$ \\
\hline Industry Avg Female Pct on Board & $\begin{array}{l}-17.38 \\
(24.13)\end{array}$ & $\begin{array}{l}-14.66 \\
(24.31)\end{array}$ & $\begin{array}{c}-258.17 * * \\
(67.83)\end{array}$ & & & $\begin{array}{l}-2.10 \\
(1.15)\end{array}$ & $\begin{array}{l}-2.00 \\
(1.11)\end{array}$ & $\begin{array}{c}-9.49 * * \\
(2.50)\end{array}$ & & \\
\hline $\begin{array}{l}\text { Industry Pct Firms with Diversity } \\
\text { Policy }\end{array}$ & & & & $\begin{array}{l}-4.45 \\
(2.87)\end{array}$ & $\begin{array}{c}-35.85^{* *} \\
(7.43)\end{array}$ & & & & $\begin{array}{l}0.37 * * \\
(0.11)\end{array}$ & $\begin{array}{l}-0.32 \\
(0.29)\end{array}$ \\
\hline Return on Assets & & & & & & $\begin{array}{l}-0.00 \\
(0.00)\end{array}$ & $\begin{array}{l}-0.00 \\
(0.00)\end{array}$ & $\begin{array}{l}-0.00 \\
(0.00)\end{array}$ & $\begin{array}{l}-0.00 \\
(0.00)\end{array}$ & $\begin{array}{l}-0.00 \\
(0.00)\end{array}$ \\
\hline Constant & $\begin{array}{c}0.30 \\
(10.57)\end{array}$ & $\begin{array}{c}21.86 \\
(18.76)\end{array}$ & $\begin{array}{c}26.09 * * \\
(7.10)\end{array}$ & $\begin{array}{c}25.58 \\
(18.49)\end{array}$ & $\begin{array}{l}23.50 * \\
(9.38)\end{array}$ & $\begin{array}{c}0.20 \\
(0.43)\end{array}$ & $\begin{array}{c}0.62 \\
(0.89)\end{array}$ & $\begin{array}{l}1.08 * * \\
(0.23)\end{array}$ & $\begin{array}{c}0.95 \\
(0.87)\end{array}$ & $\begin{array}{c}0.48 \\
(0.38)\end{array}$ \\
\hline Observations & 3,965 & 3,965 & 3,965 & 3,965 & 3,965 & 3,965 & 3,965 & 3,965 & 3,965 & 3,965 \\
\hline Number of firms & 1,050 & 1,050 & 1,050 & 1,050 & 1,050 & 1,050 & 1,050 & 1,050 & 1,050 & 1,050 \\
\hline ROA at $\mathrm{t}-1$ & Yes & Yes & Yes & Yes & Yes & & & & & \\
\hline ROA at $t-2$ & Yes & Yes & Yes & Yes & Yes & & & & & \\
\hline $\mathrm{ROA}$ at $\mathrm{t}-3$ & Yes & Yes & Yes & Yes & Yes & & & & & \\
\hline Tobins' $\mathrm{Q}$ at t-1 & & & & & & Yes & Yes & Yes & Yes & Yes \\
\hline Tobin's $\mathrm{Q}$ at $\mathrm{t}-2$ & & & & & & Yes & Yes & Yes & Yes & Yes \\
\hline Tobin's Q at t-3 & & & & & & Yes & Yes & Yes & Yes & Yes \\
\hline
\end{tabular}


Table 6 Predicting Firm Performance, Random Effects Models

\begin{tabular}{|c|c|c|c|c|c|c|c|c|c|c|}
\hline \multirow[b]{2}{*}{ Variable } & \multicolumn{5}{|c|}{ ROA } & \multicolumn{5}{|c|}{ Tobin's Q } \\
\hline & (1) & (2) & (3) & (4) & (5) & (6) & $(7)$ & (8) & (9) & (10) \\
\hline \multirow[t]{3}{*}{ Gender Diversity (t-1) } & 0.23 & $-27.33 * *$ & $-11.99 *$ & - & - & 0.19 & -0.76 & -0.48 & -0.96 & -0.58 \\
\hline & & & & $\begin{array}{c}28.14 * \\
*\end{array}$ & $\begin{array}{c}24.16^{*} \\
*\end{array}$ & & & & & \\
\hline & (1.98) & (10.04) & $(5.53)$ & $(10.49)$ & $(5.10)$ & $(0.12)$ & $(0.54)$ & $(0.37)$ & $(0.53)$ & $(0.31)$ \\
\hline \multirow{2}{*}{$\begin{array}{l}\text { Gender Diversity (t-1) x Country Avg } \\
\text { Female Pct on Board }\end{array}$} & & $60.25 * *$ & & & & & 2.10 & & & \\
\hline & & (23.29) & & & & & (1.28) & & & \\
\hline \multirow{2}{*}{$\begin{array}{l}\text { Gender Diversity (t-1) x Industry Avg } \\
\text { Female Pct on Board }\end{array}$} & & & $150.65^{*}$ & & & & & 8.16 & & \\
\hline & & & (64.33) & & & & & $(4.34)$ & & \\
\hline \multirow{2}{*}{$\begin{array}{l}\text { Gender Diversity (t-1) x Country Pct } \\
\text { Firms with Diversity Policy }\end{array}$} & & & & $15.37 *$ & & & & & $0.89 *$ & \\
\hline & & & & $(6.81)$ & & & & & $(0.35)$ & \\
\hline \multirow{3}{*}{$\begin{array}{l}\text { Gender Diversity (t-1) x Industry Pct } \\
\text { Firms with Diversity Policy }\end{array}$} & & & & & $44.02 *$ & & & & & $1.37 * *$ \\
\hline & & & & & $*$ & & & & & \\
\hline & & & & & $(8.45)$ & & & & & $(0.51)$ \\
\hline \multirow{2}{*}{$\begin{array}{l}\text { Gender Diversity (t-1) x Country Laws } \\
\text { Supporting Women at Work }\end{array}$} & & $3.03 *$ & & $2.64 *$ & & & 0.10 & & 0.08 & \\
\hline & & $(1.25)$ & & $(1.25)$ & & & $(0.06)$ & & $(0.07)$ & \\
\hline \multirow[t]{2}{*}{ Debt to Equity Ratio (log) } & - & $-1.96 * *$ & $-1.95 * *$ & $-1.95 * *$ & $-1.92 * *$ & $-0.05 * *$ & $-0.05 * *$ & $-0.05 * *$ & $-0.05 * *$ & $-0.05^{* *}$ \\
\hline & $\begin{array}{l}1.96 * * \\
(0.17)\end{array}$ & $(0.17)$ & $(0.17)$ & $(0.17)$ & $(0.17)$ & $(0.01)$ & $(0.01)$ & $(0.01)$ & $(0.01)$ & $(0.01)$ \\
\hline \multirow[t]{2}{*}{ Total Employees (log) } & -0.14 & -0.11 & -0.14 & -0.13 & -0.15 & $-0.01 *$ & $-0.01 *$ & $-0.01 *$ & $-0.01 *$ & $-0.01 *$ \\
\hline & $(0.13)$ & (0.13) & (0.13) & $(0.13)$ & (0.13) & $(0.00)$ & $(0.00)$ & $(0.00)$ & $(0.00)$ & $(0.00)$ \\
\hline \multirow[t]{2}{*}{ Employee Turnover (in pct) } & 0.85 & 0.84 & $0.87 *$ & 0.86 & $0.88 *$ & $0.03 *$ & $0.03 *$ & $0.03 *$ & $0.03 *$ & $0.03 *$ \\
\hline & $(0.44)$ & $(0.44)$ & $(0.44)$ & $(0.44)$ & $(0.45)$ & $(0.01)$ & $(0.01)$ & $(0.01)$ & $(0.01)$ & $(0.01)$ \\
\hline \multirow[t]{2}{*}{ Firm Diversity Policy } & 0.07 & 0.11 & 0.07 & 0.14 & 0.26 & 0.04 & 0.04 & 0.04 & 0.04 & 0.04 \\
\hline & $(0.44)$ & $(0.44)$ & $(0.43)$ & $(0.44)$ & $(0.43)$ & $(0.02)$ & $(0.02)$ & $(0.02)$ & $(0.02)$ & $(0.02)$ \\
\hline \multirow[t]{2}{*}{ Female Pct on Boards } & 1.96 & 1.80 & 1.96 & 1.97 & 2.08 & -0.05 & -0.06 & -0.05 & -0.05 & -0.05 \\
\hline & $(1.96)$ & $(1.96)$ & $(1.95)$ & $(1.94)$ & $(1.92)$ & $(0.08)$ & $(0.08)$ & $(0.08)$ & $(0.08)$ & $(0.08)$ \\
\hline Industry Avg Female Pct on Board & $\begin{array}{c}8.04 \\
(9.45)\end{array}$ & $\begin{array}{c}6.61 \\
(9.54)\end{array}$ & $\begin{array}{l}-51.01 * \\
(25.96)\end{array}$ & & & $\begin{array}{l}-0.20 \\
(0.59)\end{array}$ & $\begin{array}{l}-0.21 \\
(0.59)\end{array}$ & $\begin{array}{l}-3.34 \\
(1.85)\end{array}$ & & \\
\hline \multirow[t]{2}{*}{ Industry Pct Firms with Diversity Policy } & & & & 1.13 & $\begin{array}{c}- \\
17.50 * \\
*\end{array}$ & & & & 0.07 & -0.51 \\
\hline & & & & $(2.22)$ & $(4.08)$ & & & & $(0.12)$ & $(0.27)$ \\
\hline \multirow[t]{2}{*}{ Return on Assets } & & & & & & $0.01 * *$ & $0.01 * *$ & $0.01 * *$ & $0.01 * *$ & $0.01 * *$ \\
\hline & & & & & & $(0.00)$ & $(0.00)$ & $(0.00)$ & $(0.00)$ & $(0.00)$ \\
\hline \multirow[t]{2}{*}{ Constant } & $\begin{array}{c}16.01 * \\
*\end{array}$ & $27.69 * *$ & $19.39 * *$ & & & 0.20 & $0.60 *$ & 0.04 & & \\
\hline & $(1.92)$ & $(4.52)$ & $(2.45)$ & & & $(0.12)$ & $(0.25)$ & $(0.21)$ & & \\
\hline Observations & 5,006 & 5,006 & 5,030 & 5,006 & 5,006 & 5,006 & 5,006 & 5,006 & 5,006 & 5,006 \\
\hline R-squared & 0.18 & 0.18 & 0.18 & 0.18 & 0.18 & 0.44 & 0.44 & 0.44 & 0.44 & 0.44 \\
\hline Number of firms & 1,069 & 1,069 & 1,069 & 1,069 & 1,069 & 1,069 & 1,069 & 1,069 & 1,069 & 1,069 \\
\hline Firm fixed effects & Yes & Yes & Yes & Yes & Yes & Yes & Yes & Yes & Yes & Yes \\
\hline Country-year fixed effects & Yes & Yes & Yes & Yes & Yes & Yes & Yes & Yes & Yes & Yes \\
\hline
\end{tabular}


Figure 1 Institutional Legitimacy of Gender Diversity

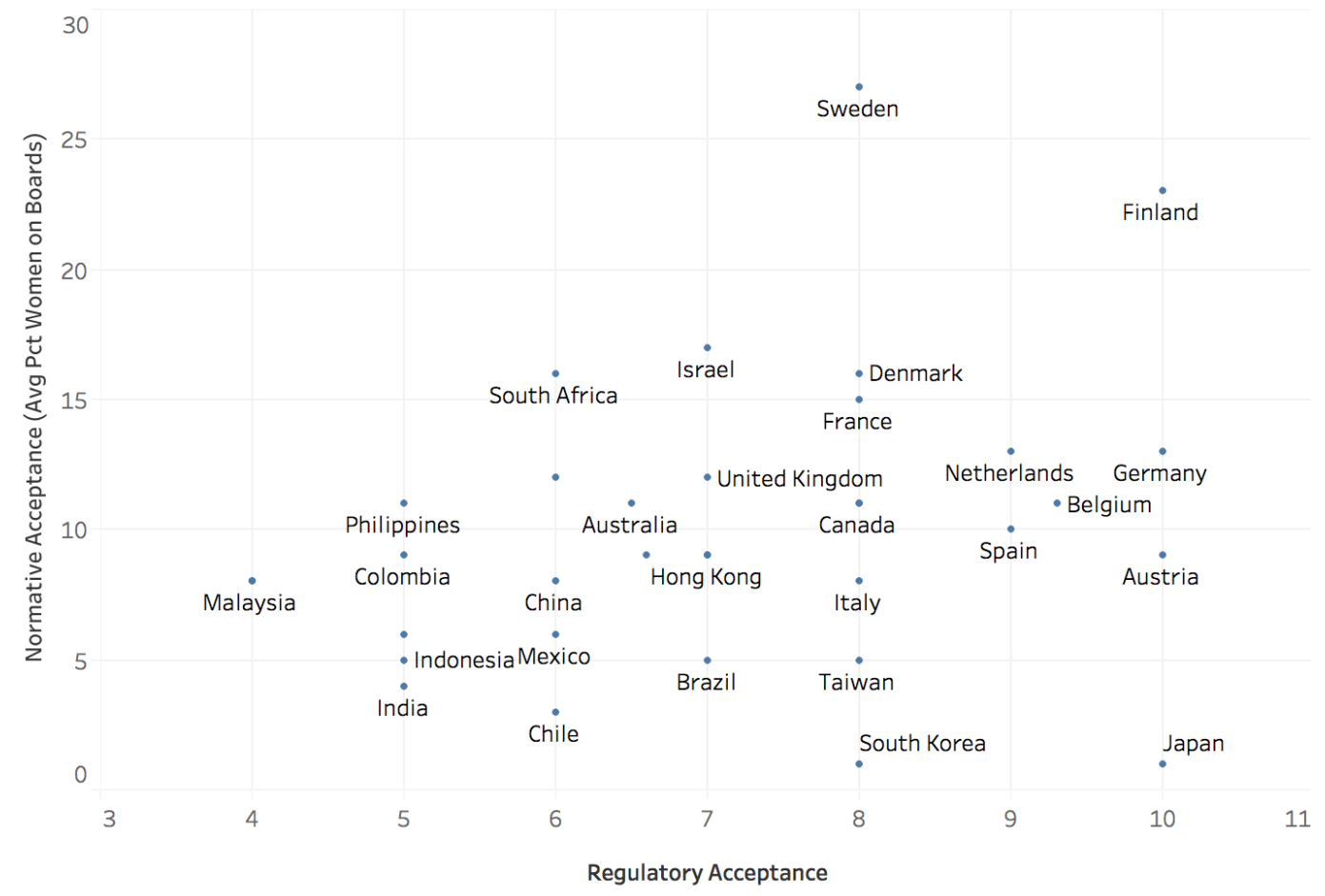




\section{Appendix 1 Constructing the Variable Country Laws Supporting Women at Work}

Since 2010, the World Bank Group has published biannual reports on over 140 countries, documenting the legal environment for women in the workplace (part of the Women, Business, and the Law project). In 2016, it issued a score for each country, based on 16 questions in the report that best reflect the country's legal conditions for women in the workplace. Since my sample covers the period from 2007 to 2014, I used the 2010 and 2012 reports to construct the score. Those reports contain only 11 of the 16 questions. The questions are listed below: each requires a yes or no answer. A country's index is simply the number of yes answers. I used the 2010 report to measure a country's score from 2007 to 2012 and the 2012 report to measure its score from 2013 to 2014.

Questions used to construct Country Laws Supporting Women at Work

1. Is there paid leave available to women of at least 14 weeks?

2. Do women receive at least $2 / 3$ of their wages for the first 14 weeks or the duration of the leave if it is shorter?

3. Are the maternity leave benefits paid by the government?

4. Is there paid parental leave?

5. Does the law mandate equal remuneration for work of equal value?

6. Is dismissal of pregnant workers prohibited?

7. Can parents work flexibly?

8. Can women work the same night hours as men?

9. Can women work in jobs deemed hazardous, arduous or morally inappropriate in the same way as men?

10. Are the ages at which men and women can retire with full pension benefits equal?

11. Are the ages at which men and women can retire with partial pension benefits equal? 